OPEN ACCESS

Edited by:

Richard Inger,

University of Exeter, UK

Reviewed by:

Anthony William James Bicknell, University of Exeter, UK

Stephen Votier,

University of Exeter, UK

*Correspondence:

Yves Cherel

chere/@cebc.cnrs.fr

Specialty section:

This article was submitted to

Population Dynamics,

a section of the journal

Frontiers in Ecology and Evolution

Received: 16 October 2015

Accepted: 12 January 2016

Published: 04 February 2016

Citation:

Cherel Y, Quilffeldt P, Delord K and Weimerskirch H (2016) Combination of At-Sea Activity, Geolocation and Feather Stable Isotopes Documents Where and When Seabirds Molt.

Front. Ecol. Evol. 4:3.

doi: 10.3389/fevo.2016.00003

\section{Combination of At-Sea Activity, Geolocation and Feather Stable Isotopes Documents Where and When Seabirds Molt}

\author{
Yves Cherel $^{1 *}$, Petra Quillfeldt ${ }^{2}$, Karine Delord ${ }^{1}$ and Henri Weimerskirch ${ }^{1}$ \\ ${ }^{1}$ Centre d'Etudes Biologiques de Chizé, UMR 7372 du Centre National de la Recherche Scientifique et de l'Université de La \\ Rochelle, Villiers-en-Bois, France, ${ }^{2}$ Department of Animal Ecology and Systematics, Justus-Liebig-Universität Giessen, \\ Giessen, Germany
}

Key facets of the foraging ecology of seabirds during the inter-breeding period still remain poorly understood because of the difficulty of studying them at sea, including during the energy-demanding molting stage. Here, the extent to which three sympatric petrels (Antarctic and thin-billed prions, and blue petrel) from the subantarctic Kerguelen Islands modify their foraging ecology during molt was investigated using a combination of complementary tools, namely miniaturized saltwater immersion geolocators (GLS) and the isotopic method. Firstly, molting behavior was first characterized in the blue petrel, a reference species that is known to renew its plumage in autumn. GLS and feather stable isotopes $\left(\delta^{13} \mathrm{C}\right.$ as a proxy of the birds' foraging habitat) indicated that the post-breeding molt of blue petrel occurred in Antarctic waters. Importantly, activity recorders showed that molt was marked by a strong peak in time spent daily sitting on water, which thereafter declined to lower values during the remaining winter months. Secondly, the peak in time spent sitting on water was used as a proxy to characterize the contrasted molt strategies of the two prion species. As blue petrels demonstrated, thin-billed prions molted during the post-breeding period in cold Antarctic waters where they fed primarily on low trophic level prey, most likely Antarctic krill ( $\delta^{15} \mathrm{~N}$ as a proxy of the birds' diet). By contrast, Antarctic prions presented an unexpected pre-breeding molt of longer duration that took place further north, in warm subtropical waters. Interestingly, the two Antarctic molting species, the blue petrel and thin-billed prion, renewed their plumage at the same time and within the same oceanic zone that is likely to be a previously undescribed hot spot of seabird diversity during the Austral autumn. The study contributes to a growing body of evidence that closely-related species exhibit various foraging strategies allowing ecological segregation and sheds new light on the poorly known critical molting stage of seabirds.

Keywords: body feathers, flight feathers, inter-breeding period, petrels, Procellariiformes, Southern Ocean, winter 


\section{INTRODUCTION}

Energetic trade-offs drive the annual timing of activities that are costly in resources and time. In birds, reproduction, migration, and molt temporally concentrate energy and nutrient requirements and are thus common events that are essentially exclusive in time. Seabirds, for example, need the inter-breeding period to migrate, replenish energy reserves for the next breeding attempt, and replace plumage. Overall, importance of the interbreeding period is well-illustrated by the effects of climatic variations outside the breeding period on the reproductive phenology and population dynamics of seabirds (Grosbois and Thompson, 2005; Frederiksen et al., 2008; Schroeder et al., 2009). A challenge in identifying the underlying biological mechanisms is the lack of knowledge on their time-energy budgets and foraging strategies during this period. Specifically, more information is needed about each of the different activities occurring during the inter-breeding period, namely migration, wintering, and molt. In a few cases spectacular migration routes have been recently documented (Croxall et al., 2005; Shaffer et al., 2006; Egevang et al., 2010). Overall, however, despite years of intensive study, key facets of the inter-breeding strategies still remain poorly understood because of the difficulties of studying seabirds at that time to obtain even simple baseline data.

The recent development of miniaturized geolocators (GLS) allowed investigating the inter-breeding period at unprecedented temporal and spatial scales (Weimerskirch and Wilson, 2000; Croxall et al., 2005; Thiébot et al., 2012). GLS coupled to activity (wet/dry) recorders have depicted the migration pathways, wintering grounds and daily activity patterns of different seabird groups, with a focus on the large-ranging Procellariiformes (albatrosses, petrels, shearwaters; Mackley et al., 2010; Pinet et al., 2011; Freeman et al., 2013). Little information, however, was collected on the molting period, namely molt activity pattern and when and where seabirds renew their plumage. A recent investigation revealed a quasi-flightless stage during the inter-breeding period of Hawaiian albatrosses (Phoebastria immutabilis and Phoebastria nigripes), with the likely explanation being that it corresponds to flight impairment during active wing molt (Gutowsky et al., 2014). The main aim of the present work was to verify the latter hypothesis on a seabird species with a known molt chronology and to test it on two other species of small petrels breeding in the Southern Ocean (Kerguelen Islands). The ultimate goal was to characterize a well-defined and easily-recorded behavioral molt criterion. The use of saltwater immersion GLS was combined with the stable isotope method on feathers, which reflect the diet at the time they were grown, because keratin is inert after synthesis (Hobson and Clark, 1992, 1993; Bearhop et al., 2002). The isotopic method was validated in the southern Indian Ocean (encompassing the petrel feeding areas), with $\delta^{13} \mathrm{C}$-values of seabirds indicating their latitudinal foraging habitats (Jaeger et al., 2010b) and their $\delta^{15} \mathrm{~N}$-values increasing with trophic level (Cherel et al., 2010).

In a first step, the blue petrel (Halobaena caerulea, BP) was choosen as a reference species, because adults display new plumage during a transient autumn reoccupation of their burrows, establishing that they renew their plumage during a definite post-breeding time-window (Fugler et al., 1987). Our first hypothesis was that the time spent sitting on water would peak at that time. Our second hypothesis was that the corresponding molting areas were located in Antarctic waters, because (i) the low $\delta^{13} \mathrm{C}$-values indicated feather growth at high latitudes, and (ii) GLS data showed that blue petrels mostly remain south the Polar Front during the inter-breeding period (Cherel et al., 2002b, 2014; Quillfeldt et al., 2015a). In a second step, the occurrence of a transient increase in time spent on water was checked in two closely-related species of prions, namely the Antarctic (Pachyptila desolata AP) and thin-billed (Pachyptila belcheri, TBP) prions. Kerguelen Archipelago is the only place where the two species nest sympatrically in significant numbers. While AP and TBP show no obvious spatial and trophic segregation during breeding (Cherel et al., 2002a), both GLS data and feather $\delta^{13} \mathrm{C}$-values confirm a latitudinal segregation during the inter-breeding period, with AP and TBP favoring temperate and subantarctic/Antarctic waters, respectively (Cherel et al., 2002a; Quillfeldt et al., 2015a). However, the exact location of the molting zones within these broad oceanographic sectors is still unknown. Using the peak in time spent on water as a proxy of molt, it was thus expected that AP molt in subtropical waters, TBP in Antarctic waters, and that molt of both species occurs right after breeding, as BP does (Harper, 1980; Marchant and Higgins, 1990). Notably, the importance of the interbreeding period for $\mathrm{AP}, \mathrm{TBP}$, and $\mathrm{BP}$ is highlighted by longterm demographic studies showing that non-breeding climatic conditions shape their population dynamics (Guinet et al., 1998; Nevoux and Barbraud, 2006). For example, $70 \%$ of mortality of $\mathrm{BP}$ occurs at that time and mortality is higher during anomalous warm winter events (Barbraud and Weimerskirch, 2003).

\section{MATERIALS AND METHODS}

\section{Study Site, Birds, and Sampling}

Fieldwork was carried out at the subantarctic Kerguelen Archipelago, which is located in the northern vicinity of the Polar Front (Park and Gambéroni, 1997). The study colonies were located at two adjacent islands in the Golfe du Morbihan, where large numbers of BP, TBP (Ile Mayes, $49^{\circ} 28^{\prime} \mathrm{S}, 69^{\circ} 57^{\prime} \mathrm{E}$ ), and AP (Ile Verte, $49^{\circ} 31^{\prime} \mathrm{S}, 70^{\circ} 04^{\prime} \mathrm{E}$ ) breed. To avoid potential biases due to inter-annual variations, all birds were studied in 2012 during the inter-breeding period between the end and the beginning of the 2011/2012 and 2012/2013 breeding cycles, respectively.

Importantly, breeding chronology and colony attendance vary according to the species. The following features are notable: (i) fledging occurs in February in both BP and TBP and later, in April, in AP; (ii) unlike prions, adult BP transiently return to their burrows in autumn during a post-breeding visit (Fugler et al., 1987; Marchant and Higgins, 1990); (iii) BP return to the colony in early September, while TBP and AP arrive later, in October and November, respectively; (iv) importantly, AP lays later than the two other species, with laying occurring on average 40 days later than in its closely-relative TBP (Weimerskirch et al., 1989). Available information on molt pattern and chronology is generally scarce and depends on the species and feather 
types. For all three species, a complete molt occurs annually during the inter-breeding period. Little is known on the molt of body feathers, but primaries are renewed following a simple descendent mode from the innermost (P1) to the outermost (P10) during a 2-4 months period (Bridge, 2006). BP complete all primary, secondary and tail molts during the post-breeding exodus in February-April, known through adults exhibiting new plumage during the transient autumn reoccupation of their burrows (Fugler et al., 1987). The wing and tail molts of prions, including TBP and AP, are also expected to take place during the post-breeding period (Harper, 1980; Marchant and Higgins, 1990).

To investigate spatial movements and activity patterns during the inter-breeding period, breeding birds were equipped with miniaturized saltwater immersion geolocators, GLS loggers (MK10, developed by the British Antarctic Survey, Cambridge, UK; Afanasyev, 2004). GLS weighed $1 \mathrm{~g}(<1 \%$ of the mean body mass of the birds) and were fixed to plastic leg bands. Tagged individuals were marked with numbered steel rings on the other leg. AP, BP and TBP adults were caught in burrows twice during incubation, first on deployment of GLS, and second, on their recovery a year later. The tagged birds were the same as those from a recent brief article describing their overall species-specific wintering strategies (Quillfeldt et al., 2015a). Recovery rate of birds carrying GLS was lower in AP (55\%) than in TBP (79\%) and BP (85\%; Table 1). The most likely explanation of the difference was that fewer visits were made at the isolated Ile Verte (where AP breed) to recapture birds than at Ile Mayes (where many longterm demographic investigations on seabirds including TBP and BP are conducted). A detailed study found no evidence for any substantial impact of GLS on TBP: (i) breeding performance was unaffected in the season of attachment or following recovery, (ii) eco-physiological measurements suggested that adults adapted to the higher load, and (iii) the similarity in $\delta^{13} \mathrm{C}$ - and $\delta^{15} \mathrm{~N}$-values of blood and feathers of instrumented adults and control birds indicated that feeding ecology was unaffected (Quillfeldt et al., 2012).

A blood sample was taken from the brachial vein of birds for molecular sexing. DNA was extracted from blood cells and the chromo helicase DNA-binding (CHD) gene was amplified in a polymerase chain reaction procedure (Weimerskirch et al., 2005). A few body feathers that likely grew simultaneously to the GLS tracking were collected from the lower back of birds at recapture. Isotopic measurements were made on four body feathers per individual to better depict the species isotopic niche during molt
(Jaeger et al., 2009). Wing feathers were not sampled on live birds, because their collection impairs the birds' flying ability. Consequently, dead AP, BP, and TBP were additionally collected either after being incidentally trapped in the vegetation (AP; Carravieri et al., 2014) or after being predated by brown skuas (BP and TBP) to investigate the $\delta^{13} \mathrm{C}$ - and $\delta^{15} \mathrm{~N}$-values of flight feathers. The tip of each primary was cut as was the basal part of the vane of $\mathrm{P} 10$ in order to gather sequential isotopic information over the entire primary molt (Quillfeldt et al., 2010b), i.e., from the distal part of P1 (oldest part) to the proximal part of P10 (youngest part). Age and status of the dead specimens were unknown, but they were neither chicks nor fledglings.

\section{Processing of Positional and Immersion State Data from GLS}

Geolocators provide two positions per day based on light levels with a mean error \pm SD of $186 \pm 114 \mathrm{~km}$ (Phillips et al., 2004). Light data were analyzed using the BASTrak software suite (British Antarctic Survey, 2009). TransEdit was used to check for integrity of light curves and to determine dawn and dusk times, and Locator to estimate latitude from day length and longitude from the time of local mid-day relative to Greenwich Mean Time. A sun elevation angle of $-3.5^{\circ}$ was assumed, based on known positions obtained during pre- and post-deployment ground calibration of the loggers at the colony. All estimated locations were examined visually in a geographical information system (GIS) and any unrealistic positions-either associated with interference to light curves at dawn or dusk, or in temporal proximity to equinoxes when latitudes are unreliablewere excluded from further spatial analyses. This leads to a reduced number of observations for the periods around the equinoxes. The unfiltered data were used to obtain information about longitudinal movements during the equinox times, e.g., to define the timing of return migration that partly overlapped with equinox (Quillfeldt et al., 2015a). The timing of migration was determined from directed longitudinal movements that finished at or beyond the breeding colony longitude, as described earlier (Figure S1 in Quillfeldt et al., 2015b). In AP, a directed longitudinal movement was not clearly defined, and therefore was not included in the statistical analyses. For the same reason, the duration of the inter-breeding period was defined as the time between outward migration and inward migration in BP and TBP, and as the total time away from the colony in AP (Table 2).

The activity (i.e., saltwater contact) analyses carried out with the online tool Actave.net (Mattern et al., 2015) were used

TABLE 1 | Sample sizes of birds at geolocator (GLS) deployment and recovery, and for feather stable isotope analysis, and number of females and males and of analyzed GLS tracks.

\begin{tabular}{|c|c|c|c|c|c|c|c|}
\hline \multirow[t]{3}{*}{ Species } & \multicolumn{2}{|c|}{ GLS } & \multicolumn{2}{|c|}{ Tracks } & \multicolumn{2}{|c|}{ Sex } & \multirow{3}{*}{$\begin{array}{c}\text { Body feather } \\
\text { stable isotopes } \\
n\end{array}$} \\
\hline & Deployment & Recovery & All & Complete & Females & Males & \\
\hline & $n$ & $n(\%)$ & $n$ & $n$ & $n$ & $n$ & \\
\hline Antarctic prion & 20 & $11(55)$ & 11 & 11 & 4 & 7 & 10 \\
\hline Thin-billed prion & 29 & $23(79)$ & 17 & 15 & 11 & 12 & 23 \\
\hline Blue petrel & 20 & 17 (85) & 16 & 12 & 10 & 6 & 17 \\
\hline
\end{tabular}


TABLE 2 | Main characteristics of the inter-breeding and molting periods of Antarctic and thin-billed prions and of blue petrels from the Kerguelen Archipelago in 2012.

\begin{tabular}{|c|c|c|c|c|}
\hline Parameter & Antarctic prion & Thin-billed prion & Blue petrel & Statistics \\
\hline \multicolumn{5}{|l|}{ INTER-BREEDING PERIOD } \\
\hline Departure date (days) & (11) 13 April $\pm 12^{a}$ & (19) 15 February $\pm 9^{b}$ & (15) 05 February $\pm 4^{c}$ & $F_{(2,42)}=210.1, p<0.0001$ \\
\hline Arrival date & (11) 28 November $\pm 12^{a}$ & (15) 11 October $\pm 3^{b}$ & (12) 09 September $\pm 4^{c}$ & $F_{(2,35)}=373.0, p<0.0001$ \\
\hline Duration (days) & (11) $230 \pm 15^{\mathrm{a}}$ & (15) $239 \pm 10^{a}$ & (12) $218 \pm 6^{b}$ & $F_{(2,35)}=13.8, p<0.0001$ \\
\hline Distance (km) & $(11) 53559 \pm 9457^{a}$ & (13) $65019 \pm 6801^{b}$ & (12) $77566 \pm 8531^{c}$ & $F_{(2,33)}=24.3, p<0.0001$ \\
\hline Maximum distance from the colony (km) & $(11) 4013 \pm 1312^{a}$ & (17) $4941 \pm 819^{b}$ & (15) $5090 \pm 522^{b}$ & $F_{(2,40)}=5.2, p=0.010$ \\
\hline Travel speed (km/day) & (11) $233 \pm 40^{\mathrm{a}}$ & (13) $274 \pm 27^{b}$ & (12) $357 \pm 38^{C}$ & $F_{(2,33)}=37.1, p<0.0001$ \\
\hline \multicolumn{5}{|l|}{ MOLTING PERIOD } \\
\hline Beginning date (days) & (11) 27 July $\pm 8^{a}$ & (15) 20 February $\pm 9^{b}$ & (13) 07 February $\pm 6^{c}$ & $F_{(2,36)}=1795.0, p<0.0001$ \\
\hline Duration (days) & (11) $109 \pm 13^{a}$ & (15) $83 \pm 13^{\mathrm{b}}$ & (13) $71 \pm 4^{\mathrm{c}}$ & $F_{(2,36)}=38.7, p<0.0001$ \\
\hline Centroid longitude $\left({ }^{\circ} \mathrm{E}\right)$ & (11) $86.2 \pm 35.0^{a}$ & (15) $14.4 \pm 4.3^{b}$ & (13) $12.6 \pm 25.2^{b}$ & $F_{(2,36)}=37.3, p<0.0001$ \\
\hline Centroid latitude $\left({ }^{\circ} \mathrm{S}\right)$ & (15) $39.1 \pm 2.6^{a}$ & (15) $57.0 \pm 2.6^{b}$ & (13) $58.5 \pm 3.7^{b}$ & $F_{(2,36)}=152.6, p<0.0001$ \\
\hline $90 \%$ Kernel area, all individuals pooled $\left(10^{3} \cdot \mathrm{km}^{2}\right)$ & 9678 & 3090 & 5427 & - \\
\hline
\end{tabular}

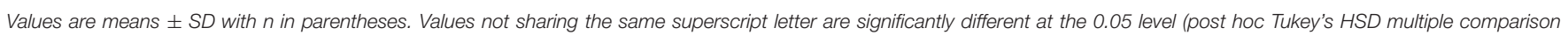
tests).

to describe the birds' behavior at sea. The devices recorded saltwater immersion every $3 \mathrm{~s}$ as proxy for activity patterns and store the sum of positive tests once every $10 \mathrm{~min}$. Hence, each recorded time-stamped immersion value (denoted $\varepsilon$ ) can range from 0 (no immersion) to 200 (permanent immersion). Actave.net's standard setting define immersion as follows (i) time in flight: the sum of all 10-min intervals with $\varepsilon=0$ (dry), (ii) time (sitting) on water: the sum of 10-min intervals with $\varepsilon=200$ (wet), and (iii) foraging time: the sum of 10 -min intervals with $0<\varepsilon<200$ (intermediate). Hence, the bird's behavior was defined using the less arbitrary and most conservative threshold $\varepsilon$ values, namely 0 and 200. BP and prions use different feeding techniques, including surfaceseizing, surface-filtering, shallow-plunging, hydroplaning, and dipping (Marchant and Higgins, 1990). These methods involve actively transitioning from air to water; accordingly, foraging time was here identified as intermittent wet and dry states for at least one $10 \mathrm{~min}$ period. Although such records probably include non-foraging behaviors (e.g., preening, stretching), we believe that they represent a reasonable indicator of foraging activity of the birds (McKnight et al., 2011). Note that in most previous studies using wet/dry recorders, only two activities were quantified, corresponding to the total time per day either when the sensor was wet (on water) or dry (in flight/on land; Afanasyev, 2004; Catry et al., 2009). They were also calculated here to facilitate behavioral comparisons. Theoretically, time in flight cannot be distinguished from time on land. Here, the presence on land of burrowing petrels during the interbreeding period was detected with light and activity data, and the corresponding $\varepsilon$-values were deleted; it only occurred in BP during the post-breeding visits to the colony in autumn (see below).

The following values were extracted using Actave for each individual (Table 3):

- Daily time in flight: the amount of time a bird spent continuously in the air per day $(\varepsilon=0)$;
- Daily time on water: the amount of time a bird spend continuously on water per day $(\varepsilon=200)$;

- Daily foraging time: the amount of time the logger registered both wet and dry periods per day $(0<\varepsilon<200)$;

- Foraging time at night: the amount of time a bird foraged at night, that is the time from midnight to the start of the morning twilight hours and the time from the end of evening twilight hours until the following midnight;

- Foraging time during the day: the amount of time a bird foraged during the daylight hours, that is from sunrise to sunset;

- Daily flight bouts: number of dry bouts;

- Flight bout duration: mean duration of dry bouts.

Using all these values, we calculated means for each individual and period (i.e., total Inter-breeding period, Molting period and the remaining part of the inter-breeding period, termed Nonmolting period).

\section{Molt Definition and Characteristics}

For each individual, molt was characterized using the transient peak in time spent on water by the birds during the interbreeding period (Figure 1). It was defined as the time window (consecutive days) during which daily time on water was $\geq$ $50 \%$ of the maximum value of daily time on water for that individual (Table 2). Consequently, the transient peak in time spent on water allowed splitting the inter-breeding period of each individual bird into two contrasted periods, molting and non-molting, which were analyzed separately and compared (Table 3). Light data corresponding to the molt period were extracted from the whole data set of each individual bird. This was achieved using three steps: (i) extraction of daily data of activity using the Actave tool (Mattern et al., 2015), (ii) fitting a GAM on the variable "onwater" (i.e., the total time spent on water) separately for each individual, and (iii) calculating the dates when the fitted "onwater" value exceeded $50 \%$ of the maximum (resulting in a broader area, called the extended molt 
TABLE 3 | At-sea activities during the inter-breeding and molting periods of Antarctic and thin-billed prions and of blue petrels from the Kerguelen Archipelago in 2012.

\begin{tabular}{|c|c|c|c|c|}
\hline Parameter & Antarctic prion $(n=11)$ & Thin-billed prion $(n=14-15)$ & Blue petrel $(n=12)$ & Statistics \\
\hline \multicolumn{5}{|l|}{ INTER-BREEDING PERIOD } \\
\hline Daily time on water (h, \%) & $3.9 \pm 1.5^{\mathrm{a}}(16.1 \pm 6.3)$ & $3.5 \pm 1.0^{\mathrm{a}}(14.5 \pm 4.3)$ & $3.6 \pm 0.7^{a}(15.1 \pm 3.1)$ & $F_{(2,35)}=0.4, p=0.681$ \\
\hline Daily time in flight (h, \%) & $6.0 \pm 1.8^{\mathrm{a}}(24.8 \pm 7.4)$ & $5.1 \pm 1.4^{\mathrm{a}}(21.2 \pm 6.0)$ & $8.8 \pm 1.6^{b}(36.8 \pm 6.8)$ & $F_{(2,35)}=19.8, p<0.0001$ \\
\hline Daily foraging time (h, \%) & $14.2 \pm 2.1^{\mathrm{a}}(59.1 \pm 8.7)$ & $15.4 \pm 1.0^{\mathrm{a}}(64.3 \pm 4.3)$ & $11.5 \pm 1.1^{\mathrm{b}}(48.1 \pm 4.4)$ & $F_{(2,35)}=25.4, p<0.0001$ \\
\hline Foraging time during the day (h) & $7.5 \pm 0.9^{a}$ & $7.1 \pm 0.4^{a}$ & $4.5 \pm 0.7^{b}$ & $F_{(2,35)}=32.5, p<0.0001$ \\
\hline Foraging time at night (h) & $5.7 \pm 1.7^{\mathrm{a}}$ & $6.3 \pm 0.8^{a}$ & $6.0 \pm 0.9^{a}$ & $F_{(2,35)}=0.8, p=0.438$ \\
\hline Daily flight bouts (n) & $7.9 \pm 1.7^{\mathrm{a}}$ & $7.0 \pm 1.6^{\mathrm{a}}$ & $13.7 \pm 2.6^{b}$ & $F_{(2,35)}=42.7, p<0.0001$ \\
\hline Flight bout duration (min) & $47 \pm 8^{a}$ & $45 \pm 5^{\mathrm{a}}$ & $48 \pm 16^{a}$ & $F_{(2,35)}=0.3, p=0.752$ \\
\hline \multicolumn{5}{|l|}{ MOLTING PERIOD } \\
\hline Maximum time on water (h) & (11) $7.2 \pm 3.1^{a}$ & (15) $8.9 \pm 1.5^{a, b}$ & (13) $10.7 \pm 2.5^{b}$ & $F_{(2,36)}=6.3, p=0.005$ \\
\hline Daily time on water (h, \%) & $6.7 \pm 2.8^{\mathrm{a}}(27.9 \pm 11.9)$ & $8.6 \pm 1.5^{\mathrm{a}}(35.7 \pm 6.1)$ & $10.6 \pm 2.2^{b}(44.3 \pm 9.0)$ & $F_{(2,36)}=9.9, p<0.0001$ \\
\hline Daily time in flight (h, \%) & $4.1 \pm 2.2^{\mathrm{a}}(17.2 \pm 9.1)$ & $1.1 \pm 0.4^{\mathrm{b}}(4.7 \pm 1.8)$ & $3.6 \pm 2.0^{\mathrm{a}}(14.9 \pm 8.1)$ & $F_{(2,36)}=34.7, p<0.0001$ \\
\hline Daily foraging time (h, \%) & $13.2 \pm 3.1^{\mathrm{a}}(54.8 \pm 13.0)$ & $14.3 \pm 1.5^{\mathrm{a}}(59.6 \pm 6.3)$ & $9.8 \pm 1.1^{\mathrm{b}}(40.8 \pm 4.8)$ & $F_{(2,36)}=18.5, p<0.0001$ \\
\hline Foraging time during the day (h) & $6.8 \pm 1.7^{a}$ & $5.6 \pm 0.6^{b}$ & $4.7 \pm 0.9^{b}$ & $F_{(2,36)}=10.6, p<0.0001$ \\
\hline Foraging time at night (h) & $5.5 \pm 2.1^{\mathrm{a}}$ & $6.6 \pm 1.5^{\mathrm{a}}$ & $3.0 \pm 0.8^{b}$ & $F_{(2,36)}=20.0, p<0.0001$ \\
\hline Daily flight bouts (n) & $6.0 \pm 2.4^{a}$ & $3.2 \pm 0.6^{b}$ & $5.3 \pm 1.7^{\mathrm{a}}$ & $F_{(2,36)}=10.1, p<0.0001$ \\
\hline Flight bout duration (min) & $41 \pm 11^{\mathrm{a}}$ & $23 \pm 5^{b}$ & $40 \pm 13^{a}$ & $F_{(2,36)}=14.9, p<0.0001$ \\
\hline \multicolumn{5}{|l|}{ NON-MOLTING PERIOD } \\
\hline Daily time on water (h, \%) & $2.6 \pm 0.9^{a}(10.7 \pm 3.8)$ & $2.3 \pm 0.5^{a, b}(9.5 \pm 2.1)$ & $1.8 \pm 0.5^{\mathrm{b}}(7.4 \pm 1.9)$ & $F_{(2,34)}=4.6, p=0.017$ \\
\hline Daily time in flight (h, \%) & $6.8 \pm 1.7^{\mathrm{a}}(28.4 \pm 7.2)$ & $5.8 \pm 0.6^{a}(24.1 \pm 2.6)$ & $10.2 \pm 1.7^{b}(42.7 \pm 7.0)$ & $F_{(2,34)}=35.0, p<0.0001$ \\
\hline Daily foraging time (h, \%) & $14.6 \pm 1.8^{a}(60.9 \pm 7.4)$ & $15.9 \pm 0.9^{a}(66.3 \pm 3.5)$ & $12.0 \pm 1.4^{b}(50.0 \pm 5.8)$ & $F_{(2,34)}=27.5, p<0.0001$ \\
\hline Foraging time during the day (h) & $7.7 \pm 0.8^{a}$ & $7.5 \pm 0.3^{a}$ & $4.4 \pm 0.7^{\mathrm{b}}$ & $F_{(2,34)}=104.3, p<0.0001$ \\
\hline Foraging time at night (h) & $5.8 \pm 1.6^{\mathrm{a}}$ & $6.3 \pm 0.8^{\mathrm{a}}$ & $6.4 \pm 1.1^{\mathrm{a}}$ & $F_{(2,34)}=0.9, p=0.415$ \\
\hline Daily flight bouts (n) & $8.7 \pm 1.5^{\mathrm{a}}$ & $7.4 \pm 0.7^{\mathrm{a}}$ & $16.0 \pm 3.3^{b}$ & $F_{(2,34)}=59.4, p<0.0001$ \\
\hline Flight bout duration (min) & $49 \pm 7^{a}$ & $49 \pm 6^{a}$ & $49 \pm 17^{a}$ & $F_{(2,34)}=0.0, p=1.000$ \\
\hline
\end{tabular}

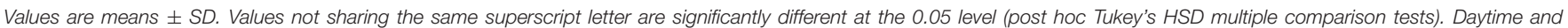
nighttime activities do not include dawn and dusk activities.

area) and when the fitted "onwater" value exceeded $75 \%$ of the maximum (resulting in a smaller area, called the core molt area). Then, the spatial distribution during molt was examined at the individual level using minimum convex hulls of filtered locations to determine density contours, while the distribution at the species level was compared using kernel analysis of filtered locations (Phillips et al., 2004). The non-parametric fixed kernel density estimator was used to determine density contours. Kernel densities do not require serial independence of observations when estimating foraging ranges (De Solla et al., 1999). Kernel analyses were performed in a Lambert equal-area azimuthal projection centered on the South Pole using ARCGIS 9.3 (ESRI, Redlands, CA, USA) and the Hawth tool (Beyer, 2004; settings: scaling factor $10^{6}$, single parameter smoothing factor: $10^{5}$, raster cell size 5000).

\section{Stable Isotopes}

Before stable isotope analysis, each whole (body feathers) or part of (primaries) individual feather was cleaned of surface lipids and contaminants using a 2:1 chloroform:methanol solution during 2 min followed by two successive methanol rinses (Jaeger et al., 2009). Feathers were then air dried and homogenized by cutting them into small fragments. Tissue sub-samples were weighed ( 0.3-0.4 mg) with a microbalance, packed in tin containers, and carbon and nitrogen isotope ratios were subsequently determined by a continuous flow mass spectrometer (Thermo Scientific Delta V Advantage) coupled to an elemental analyser (Thermo Scientific Flash EA 1112). Stable isotope concentrations were expressed in conventional notation $\left(\delta \mathrm{X}=\left[\mathrm{R}_{\text {sample }} / \mathrm{R}_{\text {standard }}\right)-\right.$ $1] \times 1000)$ where $\mathrm{X}$ is ${ }^{13} \mathrm{C}$ or ${ }^{15} \mathrm{~N}$ and $\mathrm{R}$ is the corresponding ratio ${ }^{13} \mathrm{C} /{ }^{12} \mathrm{C}$ or ${ }^{15} \mathrm{~N} /{ }^{14} \mathrm{~N}$. $\mathrm{R}_{\text {standard }}$ are Vienna PeeDee Belemnite and atmospheric $\mathrm{N}_{2}$ for $\delta^{13} \mathrm{C}$ and $\delta^{15} \mathrm{~N}$, respectively. Replicate measurements of internal laboratory standards (acetanilide) indicate measurement errors $<0.15 \%$ for both $\delta^{13} \mathrm{C}$ and $\delta^{15} \mathrm{~N}$.

The Southern Ocean is marked by a well-defined latitudinal baseline $\delta^{13} \mathrm{C}$ gradient that is reflected in the tissue of consumers (Jaeger et al., 2010b; Quillfeldt et al., 2010a). The isotopic consumer data allowed estimating $\delta^{13} \mathrm{C}$ position of the main oceanic fronts within the southern Indian Ocean and thus to delineate robust isoscapes of the main foraging zones for seabirds, depending on the targeted tissues. Based on feather $\delta^{13} \mathrm{C}$ isoscapes, values less than $-21.2 \%$, from -21.2 to $-18.3 \%$, and greater than $-18.3 \%$ were considered to correspond to the Antarctic, Subantarctic and Subtropical Zones, respectively (Jaeger et al., 2010b).

Data were statistically analyzed using SYSTAT 13 for WINDOWS (Systat Software, Chicago). Values are means \pm SD. 


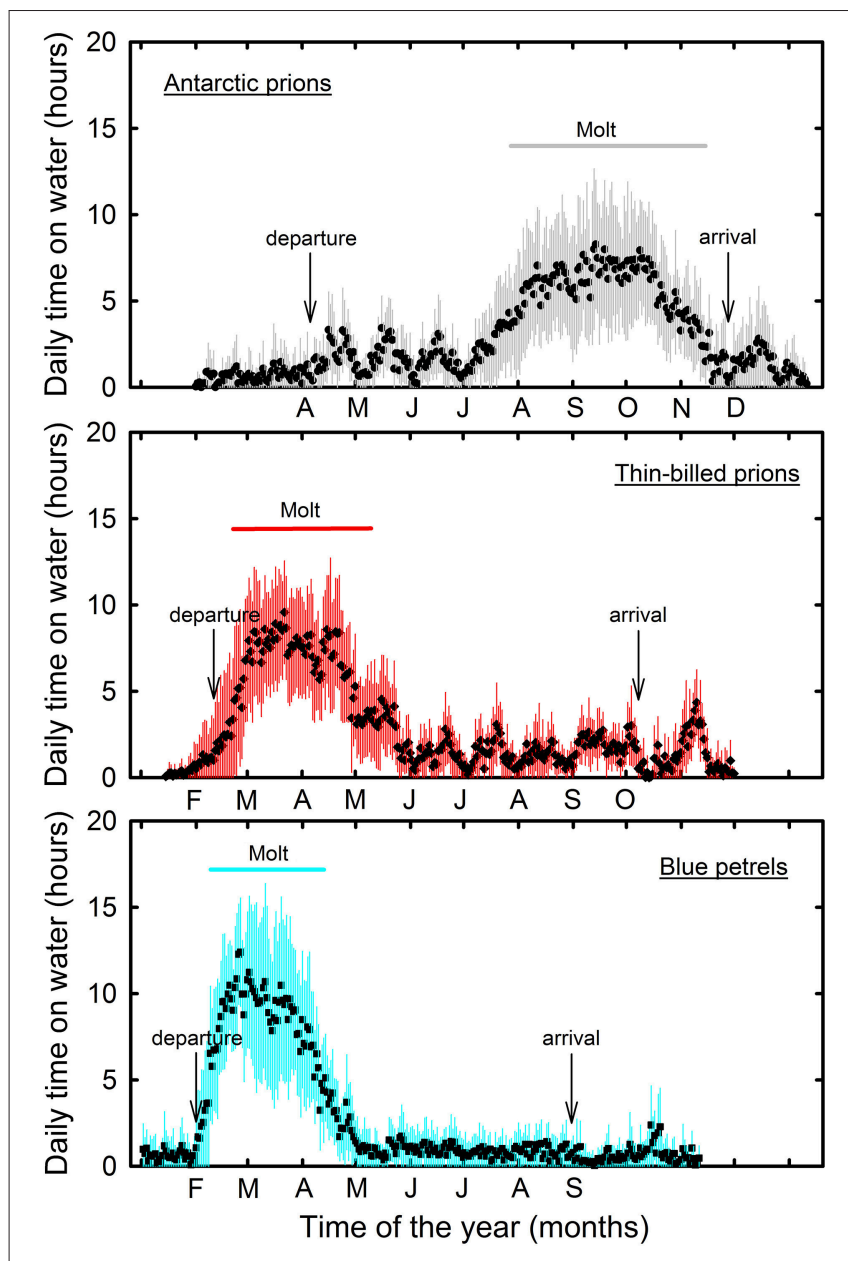

FIGURE 1 | Daily time spent sitting on the water as a proxy of daily activity patterns of Antarctic (gray) and thin-billed (red) prions and of blue petrels (blue) over the annual cycle. Molt refers to the period during which birds spent $>50 \%$ time per day sitting on water. Months refer to the species-specific inter-breeding period. Birds were equipped with miniaturized saltwater immersion geolocators. Values are means $\pm \mathrm{SD}$.

\section{RESULTS}

Potential sex-related differences were tested in the many parameters used in the present work (geolocation, activity, stable isotopes). Few results were statistically significant and they were generally significant at a marginal level and/or with low biological significance (statistics not shown). Consequently, data from both sexes were pooled in all subsequent analyses.

\section{Movements and Destinations during the Inter-Breeding Period}

Chronology of the 2012 inter-breeding period of the GLS birds was in accordance with the known phenology of the species (Table 2). Departure dates of adult BP and TBP occurred in early and mid-February and they went back to the colonies in September and October, respectively. In contrast, AP left the colonies in April and returned to their breeding grounds in
November, on average 48 days later than TBP. The transient autumn reoccupation of the burrows of $\mathrm{BP}$ was verified, with light data indicating that nine out of 12 birds spent a total of 1-8 days in burrows during 1-3 visits at the colony during the period 23 April-16 June. No other GLS birds, including prions, went back to the colonies during the inter-breeding period, with all birds remaining consistently at sea during the winter months. The inter-breeding period spanned 7-8 months and was slightly longer in prions than in BP. The corresponding total distance covered during the period increased in the order $\mathrm{AP}<\mathrm{TBP}<$ $\mathrm{BP}$, with the mean travel speed showing an identical pattern. Accordingly, the maximum distance from the colony was lower in AP than in TBP and BP ( $\sim 4000$ vs. $\sim 5000 \mathrm{~km}$, respectively).

An overall pattern of spatial segregation at sea operated during the austral winter with little changes from May to September (Figure 2). Latitudinally, AP and BP wintered in more northern and southern waters than TBP, respectively $(\sim 38-$ $42^{\circ} \mathrm{S}, 47-53^{\circ} \mathrm{S}$, and $57-62^{\circ} \mathrm{S}$, for AP, TBP, and BP, respectively). Longitudinally, TBP $\left(\sim 12-18^{\circ} \mathrm{E}\right)$ wintered further west than AP $\left(\sim 91-97^{\circ} \mathrm{E}\right)$ and $\mathrm{BP}\left(\sim 77-105^{\circ} \mathrm{E}\right)$. In contrast to winter segregation, similar movement patterns were observed in the synchronous breeders TBP and $\mathrm{BP}$ when they left the colonies in February. Individuals of both species migrated in a south-west direction to a broadly similar area in Antarctic waters. Later on, TBP stayed at similar longitudes and progressively moved further north through autumn and winter, while BP migrated back to the colony for a few days during the autumn post-nuptial stage (see above) before dispersing southeast of Kerguelen Islands in winter. There were neither well-defined outward and inward migrations in AP nor well-defined inward migration to the breeding ground in BP in late winter, but TBP flew eastward quickly to the colony during a few days ( $5 \pm 2$ days) in October during which birds reached the highest mean flight speed $(866 \pm 170 \mathrm{~km} /$ day) of any bird group.

\section{Activity Patterns, Molting Time and Molting Distribution}

Overall prions and BP spent a very large amount of time in flight. However, at some stage of the inter-breeding period, activity pattern of all BP individuals showed a transient sharp increase in time spent sitting on the water during the post-breeding period (Figure 1). The period coincides in time to molt, since BP have a fresh plumage when they migrate back to the colony in AprilJune (Fugler et al., 1987). Hence, this well-pronounced period of reduced time spent in flight was considered to be a valid criterion to define when birds renew their plumage (molting period). Indeed, it was also found during the inter-breeding period of prions. Using the Actave tool (Mattern et al., 2015) the daily time spent sitting on water during molt averaged 28,36 , and $44 \%$ in AP, TBP, and BP, respectively (Table 3). Using conventional activity analysis (Catry et al., 2009), the values even dramatically increased to 67\% (maximum: 92\%), 77\% (95\%), and 66\% (93\%), respectively.

During the non-molting period, the three species presented contrasted species-specific activity budgets. In almost all parameters, BP differed consistently from prions, with AP and TBP being similar in all. For example, (i) BP spent more time 

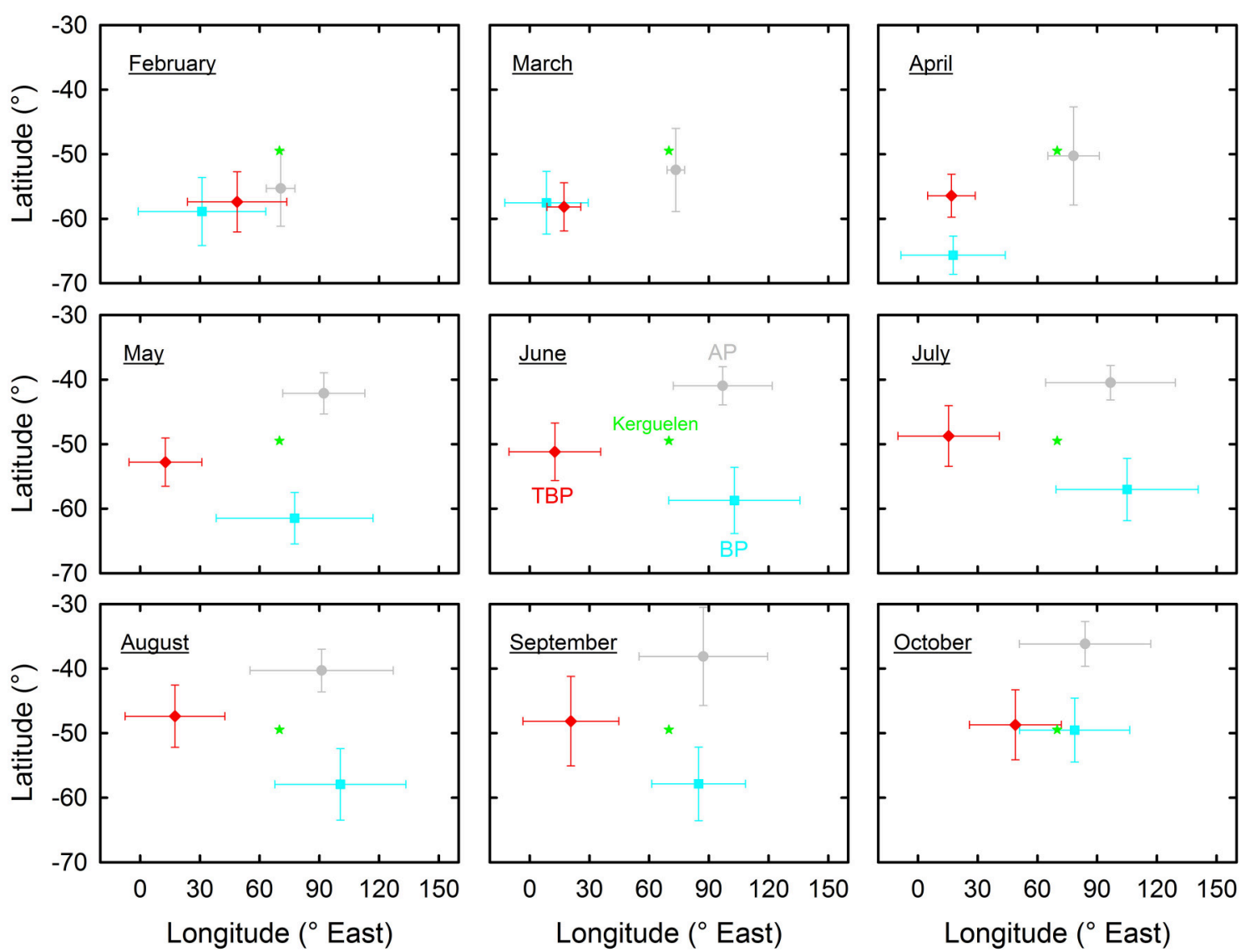

FIGURE 2 | Geographical location at sea (latitudes vs .longitudes) of Antarctic (AP, gray) and thin-billed (TBP, red) prions and of blue petrels (BP, blue) over nine successive months encompassing the whole inter-breeding period. Values are means $\pm \mathrm{SD}$ of pooled daily locations of all the birds that were equipped with miniaturized saltwater immersion geolocators.

flying and less time sitting and foraging per day than AP and TBP (flying: 43 vs. $24-28 \%$, sitting on water: 7 vs. $10-11 \%$, and foraging: 50 vs. 61-66\%). Accordingly, (ii) the daily number of flight bouts was higher in BP (16 vs. 7-9), while the mean duration of flight bouts was identical amongst species (49 min). Finally, (iii) BP foraged more at night than during daylight hours (paired $t$-test, $t=6.5, p<0.0001$ ), while prions presented an opposite pattern (both $p<0.0001$; Table 3).

By definition, AP, TBP, and BP spent more time sitting on the water per day during molt than the non-molting period (paired $t$-tests, all $p<0.0001$ ). Consequently they spent less time flying (all $p<0.0001$ ) and foraging (all $p \leq 0.040$ ) during molt. Accordingly, daily number of flight bouts (all $p<0.0001$ ) and duration of the bouts (all $p \leq 0.023$ ) were lower during the molting period. The three species were active both during the day and at night. A comparison of the molting and non-molting periods showed that foraging time during molt was lower during the day in TBP $(t=12.3, p<0.0001)$ and during the night in BP $(t=8.2, p<0.0001)$, with no significant changes in AP.

$\mathrm{BP}$ and prions presented contrasted species-specific molt strategies, the most obvious difference being the timing of molt that occurred either during the post-breeding (TBP and BP) or pre-breeding (AP) period. Molt began significantly earlier in February in BP than in TBP, while AP began molting at the end of July (Table 2). Molt duration ranged from 58 to 133 days according to individuals and it increased in the order $\mathrm{BP}<\mathrm{TBP}<\mathrm{AP}$. Mean and maximum daily time on water varied significantly in the increasing order AP $<$ TBP $<$ BP (Table 3). While molt duration derives from daily time spent on water (circularity), the relationship between the two parameters describes a biologically relevant feature (Figure 3). When individuals of the three species were pooled, mean (and maximum) daily time spent on water was negatively and linearly related to molt duration $\left[y=-0.087 x+16.245, n=39, r^{2}=\right.$ $\left.0.394, F_{(1,37)}=24.0, p<0.0001\right]$. Other notable species-specific differences during molt included (i) the very low level of daily time flying in TBP, and, accordingly its lower daily number of flight bouts and lower flight bout duration than AP and BP, (ii) the higher foraging time during the day of AP than TBP and $\mathrm{BP}$, and (iii) the lower foraging time at night of BP than prions. Spatial distribution of birds during molt showed contrasted features (Figure 4, Table 2): (i) the surface of the species molting areas increased in the order $\mathrm{TBP}<\mathrm{BP}<\mathrm{AP}$, with a ratio of 3:1 between AP and TBP; (ii) both TBP and BP molted in Antarctic 


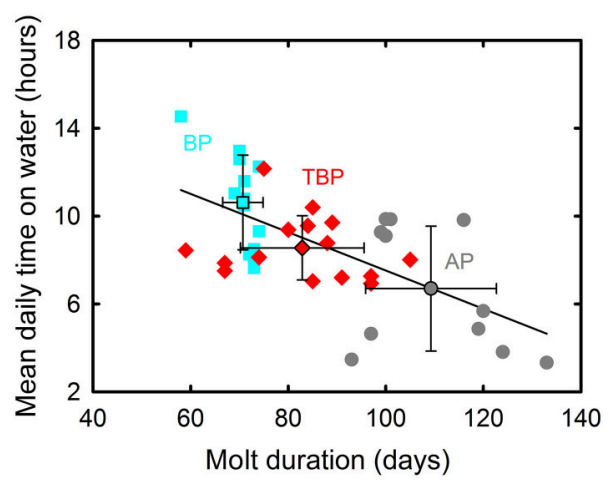

FIGURE 3 | Negative linear correlation between mean daily time on water and molt duration for individual Antarctic (gray) and thin-billed (red) prions and blue petrels (blue). Means \pm SD are also indicated. waters, with the kernel area of TBP overlapping substantially with that of BP ( $54 \%$ overlap of the extended molt areas), while the reverse was smaller ( $31 \%$ overlap); (iii) there was negligible spatial overlap of the molting grounds of TBP and $\mathrm{BP}$ with those of AP ( $<1.2 \%$ overlap); (iv) AP molted at lower latitudes that corresponded primarily to subtropical waters and secondarily to subantarctic waters, and they showed more inter-individual variability than TBP and AP.

\section{Stable Isotopes}

A total of 497 isotopic analyses were performed on feathers from 77 individuals, including 200 measurements on body feathers from GLS birds and 297 measurements on primaries of dead birds (Table 4). The overall feather $\delta^{13} \mathrm{C}$ - and $\delta^{15} \mathrm{~N}$-values of both GLS and dead birds were statistically different among species (Kruskal-Wallis one-way analysis of variances, all four
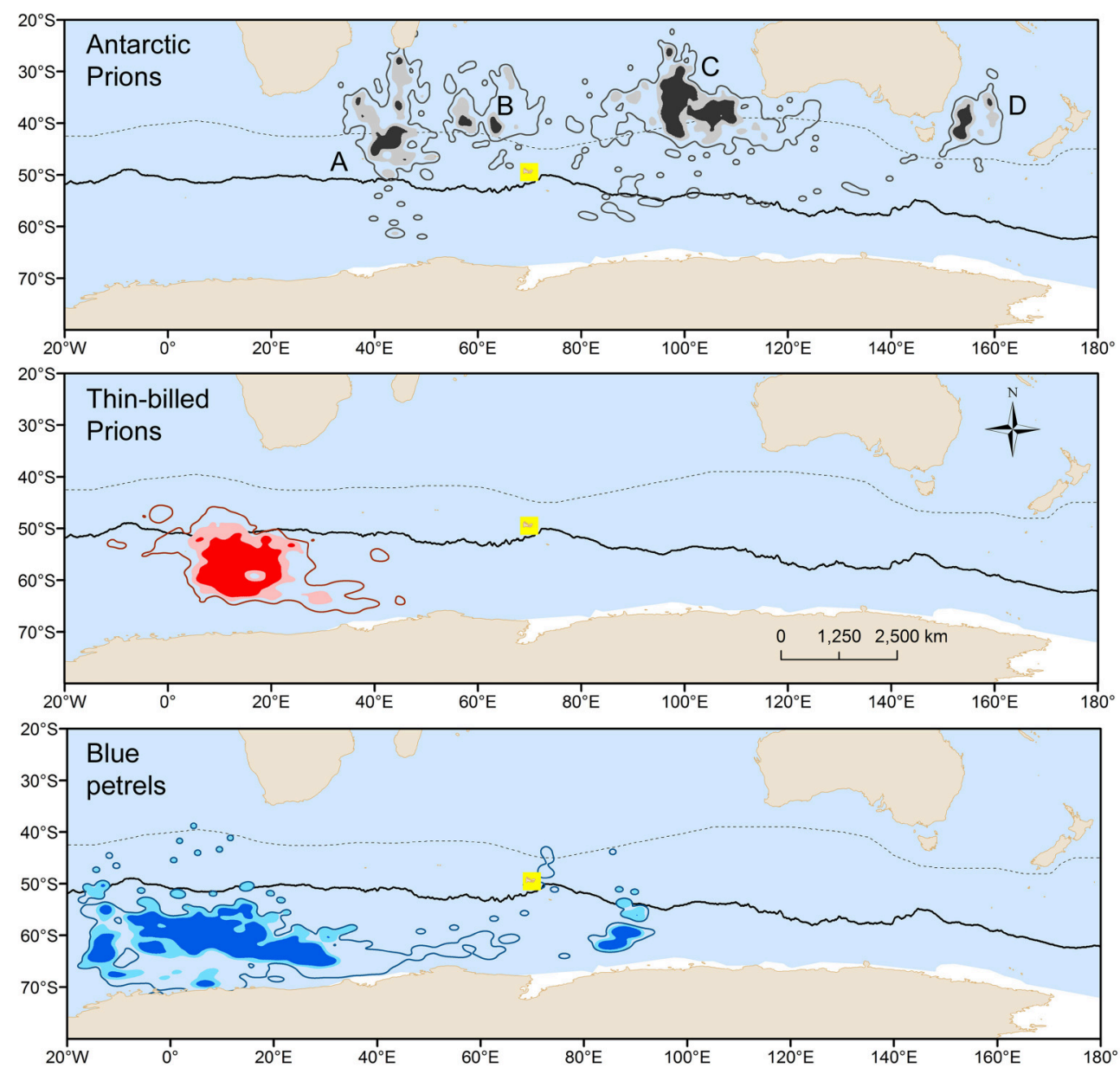

FIGURE 4 | Density contours resulting from kernel estimation of geolocation patterns of Antarctic (gray) and thin-billed (red) prions and of blue petrels (blue) during molt of flight feathers. Darker and lighter tone areas show the 75 and $90 \%$ location densities of the core molt area, i.e., according to the $75 \%$ onwater molt activity criterion, while the contours show the $90 \%$ location densities of the extended molt area, calculated using the $50 \%$ onwater molt activity criterion. A, B, C, and D refer to the molting distribution of three, one, six, and one Antarctic prions, respectively. Continuous and dashed lines refer to the Antarctic Polar Front and Subtropical Front, respectively. 


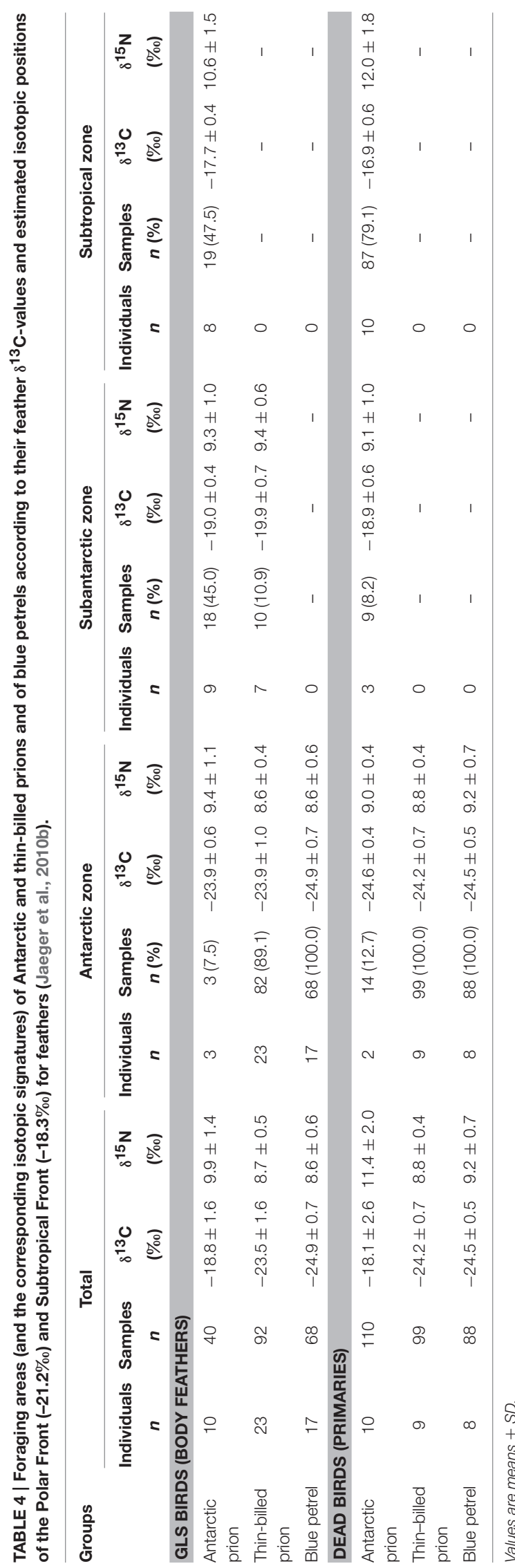

$p<0.0001)$, with feather $\delta^{13} \mathrm{C}$ - and $\delta^{15} \mathrm{~N}$-values of AP being consistently higher than those of TBP and BP (Figures 5, 6). Species-specific molt strategies were emphasized when feathers were assigned to distinct latitudinal water masses according to their $\delta^{13} \mathrm{C}$-values. The following features are noticeable: (i) all primaries and body feathers of BP grew in the Antarctic Zone; (ii) all primaries and most body feathers (89\%) of TBP also grew in the Antarctic Zone; (iii) in contrast, AP renewed most primaries (79\%) in the subtropics and almost equally body feathers in the Subtropical (48\%) and Subantarctic (45\%) Zones; (iv) only AP molted in the Subtropical Zone. When molting within the same latitudinal oceanic zone, $\mathrm{AP}, \mathrm{TBP}$, and $\mathrm{BP}$ have very similar feather $\delta^{13} \mathrm{C}$ - and $\delta^{15} \mathrm{~N}$-values (Table 4).

Feather $\delta^{13} \mathrm{C}$ - and $\delta^{15} \mathrm{~N}$-values highlighted inter- and intraindividual specific foraging strategies during molt (Figures 5, 6): (i) all BP renewed their plumage in Antarctic waters with, accordingly, little inter- and intra-individual isotopic variations; (ii) while a majority of TBP molted exclusively in the Antarctic Zone, some individuals also foraged in the Subantarctic Zone during body molt; (iii) the level of inter- and intra-individual variability was higher in AP, with two, six and two birds molting their body feathers in one, two and three distinct latitudinal oceanic zones, respectively. Eight AP replaced all their primaries in the subtropics, but two individuals showed different patterns (Figure 6): (i) one bird began its molt in Antarctic waters (P1P4), before migrating to subantarctic waters (P5) and then resuming primary molt in the subtropics (P6-P10); (ii) another bird renewed almost all its flight feathers in the Antarctic Zone and finally moved to the Subtropical Zone at the very end of molt (proximal P10).

\section{DISCUSSION}

This study shows that small petrels spend most of the interbreeding period in flight. During a time window that corresponds to molt, however, they drastically reduce flying time, spending extensive periods sitting on the water. To date, few studies based on GLS and activity data have examined the extent to which seabirds alter their foraging strategies across discrete stages of the inter-breeding period in relation to molt (e.g., Gutowsky et al., 2014), and only two have included stable isotopes in the analysis (Hedd et al., 2012; Orben et al., 2015). Here, the use of a combination of complementary methods allowed confident depiction of the molting biology of petrels (Table 5): (i) molt period was defined from analysis of activity recorder (wet/dry) data; (ii) the corresponding molting areas were extracted from GLS data; (iii) feather $\delta^{13} \mathrm{C}$-values verified the latitudinal molting habitats; (iv) feather $\delta^{15} \mathrm{~N}$-values indicated the trophic position, and hence, the marine resources used by the molting birds, and (v) in BP, the putative period of molt deduced from colony observations fits exactly with the period of reduced activity at sea.

\section{Inter-Breeding Foraging Strategies and the Non-Molting Period}

Global spatial analyses emphasized an overall latitudinal segregation of $\mathrm{BP}$ and prions during the inter-breeding period (Quillfeldt et al., 2013, 2015a; Navarro et al., 2015). Detailing 


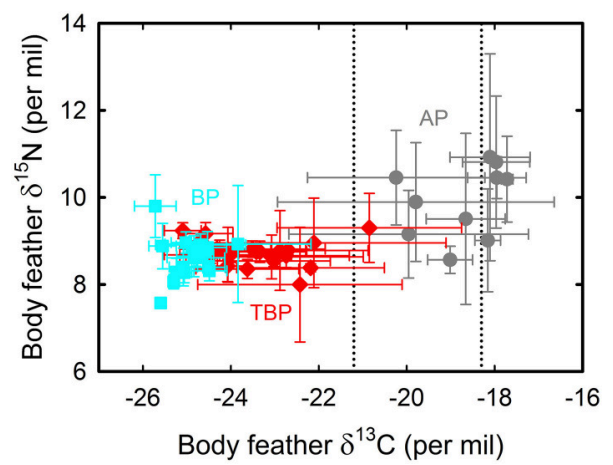

FIGURE 5 | Body feather $\delta^{13} \mathrm{C}$ - and $\delta^{15} \mathrm{~N}$-values of blue petrels (BP, blue) and of thin-billed (TBP, red) and Antarctic (AP, gray) prions that were equipped with miniaturized saltwater immersion geolocators.

Values are means \pm SD of four feathers per individual bird. Lower and upper control lines refer to the estimated $\delta^{13} \mathrm{C}$ location of the Polar Front and

Subtropical Front, respectively (Jaeger et al., 2010b).

distribution changes over time revealed new features during the inter-breeding period of Kerguelen birds. Firstly, latitudinal and longitudinal segregation operated at its maximum in winter with little species overlap from May to September. Secondly, AP favored more northern latitudes than TBP and BP all the time, but segregation of the two latter species did not occur in autumn, with the species favoring the same foraging grounds in March. Interestingly, this post-breeding spatial overlap corresponded in time to the molting period of both TBP and BP (see below).

The non-molting period of AP, TBP, and BP was marked by wintering, migration and/or dispersion. Two behavioral traits are remarkable during the period. Firstly, the flight speed of TBP during the short pre-breeding migration $(\sim 870 \mathrm{~km} /$ day $)$ is an extraordinary example of flight performance, being only comparable to the flight speed of the slightly smaller Sabine's gull (Stenhouse et al., 2012) and of larger shearwaters and albatrosses (Croxall et al., 2005; Shaffer et al., 2006; Carey et al., 2014). Secondly, time spent flying (conventional analysis; Catry et al., 2009) was higher in BP than prions (81 vs. 58-61\%). Such high times spent flying (>80\%) were only previously recorded during the daylight hours of some migrating albatrosses and petrels. Flying time on a daily basis was lower, however, because birds spent less time on the wing during darkness (Mackley et al., 2010; Hedd et al., 2012). BP is thus unique, because it flies almost continuously while foraging in the ice-free Antarctic Zone where darkness predominates in winter. The species is thus very active at night where it can dive and prey upon vertically migrating swarming crustaceans and schooling mid-water fish that form the bulk of its diet (Cherel et al., 2002b; Connan et al., 2007, 2008; Navarro et al., 2013). BP also flies almost continuously in the summer months where daylight predominates (Navarro et al., 2013; this study), thus underlining the considerable foraging plasticity of the species.

\section{Blue Petrel as a Reference Species}

A key finding of the study is that, as expected, the post-breeding temporal window during which BP renew their feathers (Fugler

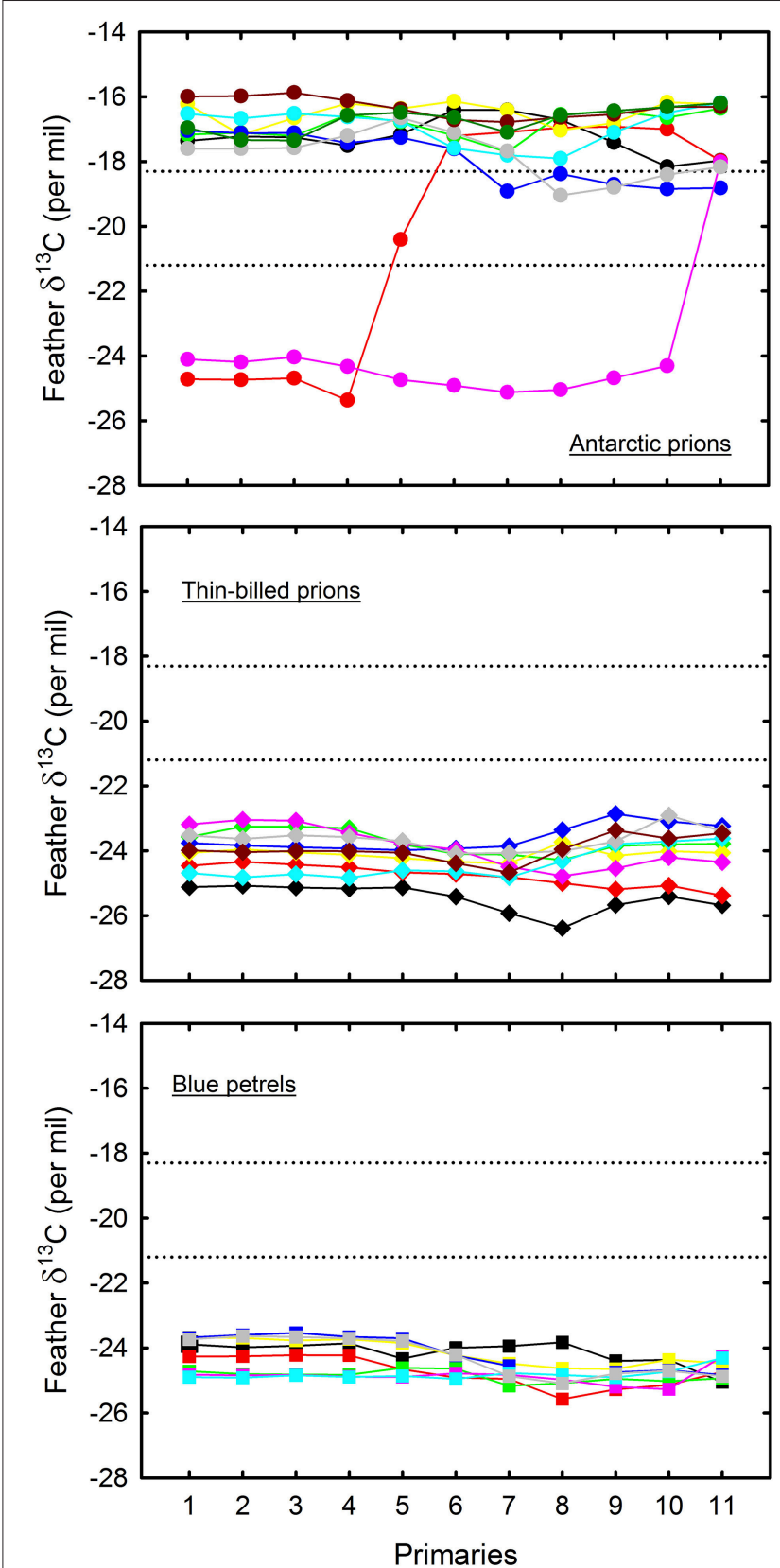

FIGURE 6 | Primary feather $\delta^{13} \mathrm{C}$ - and $\delta^{15} \mathrm{~N}$-values of blue petrels (lower panel) and of thin-billed (mid-panel) and Antarctic (upper panel) prions. Each color indicates an individual. Feathers were collected from dead birds. Numbering refers to the tip of each of the 10 primaries from the innermost (P1) to the outermost (P10) feather; 11 refers to the base of P10 and hence to the very end of primary molt. Lower and upper control lines refer to the estimated $\delta^{13} \mathrm{C}$ location of the Polar Front and Subtropical Front, respectively (Jaeger et al., 2010b).

et al., 1987) was marked by a drastic change in the birds' time-budget. The window corresponded to decreases in daily flying and foraging times, with a simultaneous correlative sharp increase in time spent sitting on water, which can be directly related to the active molt of flight feathers affecting the birds' 
TABLE 5 | Summary of molt characteristics of prions and blue petrels from Kerguelen Islands.

\begin{tabular}{|c|c|c|c|}
\hline Parameter & Antarctic prion & Thin-billed prion & Blue petrel \\
\hline Timing (activity) & Pre-breeding & Post-breeding & Post-breeding \\
\hline Molting zones (GLS) & Subtropical and subantarctic & Antarctic & Antarctic \\
\hline \multicolumn{4}{|l|}{ Molting Habitats $\left(\delta^{13} \mathrm{C}\right)$ : } \\
\hline Primaries & Subtropical (subantarctic) & Antarctic & Antarctic \\
\hline Body feathers & Subtropical and subantarctic & Antarctic (subantarctic) & Antarctic \\
\hline Inter-individual variation in molting zones (GLS) & High & Low/Medium & Low \\
\hline Inter-individual variation in molting habitats $\left(\delta^{13} \mathrm{C}\right)$ & High & Medium & Low \\
\hline Intra-individual variation in molting habitats $\left(\delta^{13} \mathrm{C}\right)$ & High & Medium & Low \\
\hline Inter-individual variation in trophic position $\left(\delta^{15} \mathrm{~N}\right)$ & High & Low/Medium & Low/Medium \\
\hline Intra-individual variation in trophic position $\left(\delta^{15} \mathrm{~N}\right)$ & High & Low/Medium & Low \\
\hline
\end{tabular}

flying ability. Re-visiting the spatial data within the molt window indicated that the distribution of BP at sea differed from that of the inter-breeding period as a whole. The distribution of most individuals remained restricted within an area centered on $\sim 13^{\circ} \mathrm{E}, 59^{\circ} \mathrm{S}$ which, as also expected, corresponds to oceanic Antarctic waters. Indeed, feather isotopic signature of the birds showed the typical low $\delta^{13} \mathrm{C}$-values of consumers feeding at high southern latitudes. Previous isotopic investigations on BP from Kerguelen and elsewhere also showed low feather $\delta^{13} \mathrm{C}$-values (Cherel et al., 2006, 2014; Navarro et al., 2015), thus indicating that molting in Antarctic waters is a consistent feature of the species. While molting, BP feed primarily on low-trophic level prey, as indicated by their relatively low feather $\delta^{15} \mathrm{~N}$-values (Cherel et al., 2006, 2014; Navarro et al., 2015; this study).

\section{Molt Strategies of Prions and Blue Petrels}

Another main finding is that a well-defined transient increase in time spent on water also occurred during the inter-breeding period of prions, thus allowing characterizing their molting period. A thorough comparison of AP, TBP, and BP reveal similarities and differences in their molting biology. In all three species, molt was only a part of the inter-breeding period. Molt duration varied among species and, interestingly, time spent on water during molt is negatively related to molt duration. Since seabirds have relatively uniform primary growth rate (Bridge, 2006), a shorter molt suggests that birds shed more old primaries and renewed more feathers simultaneously, in the decreasing order BP > TBP > AP. More shed feathers likely induce higher flight impairment, and hence more time spent on water to reduce the higher energetic cost of flying with a higher wing load.

AP and TBP are sibling species, but, surprisingly, they presented contrasted molt strategies (Table 5). Firstly, TBP underwent a post-breeding molt, as BP did, but AP showed an unexpected pre-breeding molt inconsistent with the putative post-breeding plumage renewal (Harper, 1980; Marchant and Higgins, 1990). Prions are notably difficult to identify on the wing and the age and breeding status of birds observed at sea or found dead are unknown, thus probably explaining the discrepancy. Successful AP breeders from Kerguelen Islands molt during the subsequent late winter and spring, and this timing can be easily checked for birds from southern Atlantic colonies using the activity data recorded by saltwater immersion GLS (Navarro et al., 2015) to generalize the finding. Secondly, the molting grounds of the two prions did not overlap, thus verifying the spatial segregation previously depicted using feather $\delta^{13} \mathrm{C}$-values (Cherel et al., 2002a). GLS data indicate that TBP favored Antarctic waters and AP primarily subtropical waters. Accordingly, all the TBP primaries from dead individuals showed the typical low Antarctic $\delta^{13} \mathrm{C}$-values that were similar to those of $\mathrm{BP}$, while most AP primaries had higher $\delta^{13} \mathrm{C}$-values indicating growing in the subtropics. Molting in the more productive cold Antarctic waters rather than in the less productive subtropics could explained why molt was longer in AP than in TBP and BP. Thirdly, the species molting area was three times greater in AP than BP. All TBP molted at the same place, while AP showed a high level of inter-individual variability, with birds dispersing in the subtropical Indian Ocean and one individual molting in the Tasman Sea.

The large spatial and temporal overlap between molting grounds of TBP and BP is remarkable. The area is also used by TBP from the Falklands and by light-mantled sooty albatrosses from the Crozet Islands during their presumed wing molt (Delord et al., 2013; Quillfeldt et al., 2015b; Pinet et al., unpublished data). Hence, the area is a previously unknown hot spot of seabird diversity. The low feather $\delta^{15} \mathrm{~N}$-values of TBP and BP indicate the presence of macrozooplankton, most likely Antarctic krill, in the area. It is intriguing why AP did not molt at this seabird hot spot, considering they perform long trips to Antarctic waters during chick-rearing, as TBP and BP do (Cherel et al., 2002b). The species-specific difference probably results from the late breeding phenology of AP that leave the colony 2 months later than TBP and AP. At that time, bad weather conditions prevail at high-latitudes and ice reforms, thus decreasing the availability of marine resources for the birds.

\section{Molt of Primaries and Body Feathers}

The study of feathers provides a unique opportunity to trace movements through analyses of intrinsic markers (Cherel et al., 2000; Gonzalez-Solis et al., 2011). Accordingly, $\delta^{13} \mathrm{C}$-values of primaries that were opportunistically sampled from naturally dead BP and prions fit well with the GLS data from live birds. Two AP individuals were exceptions by displaying partial molt 


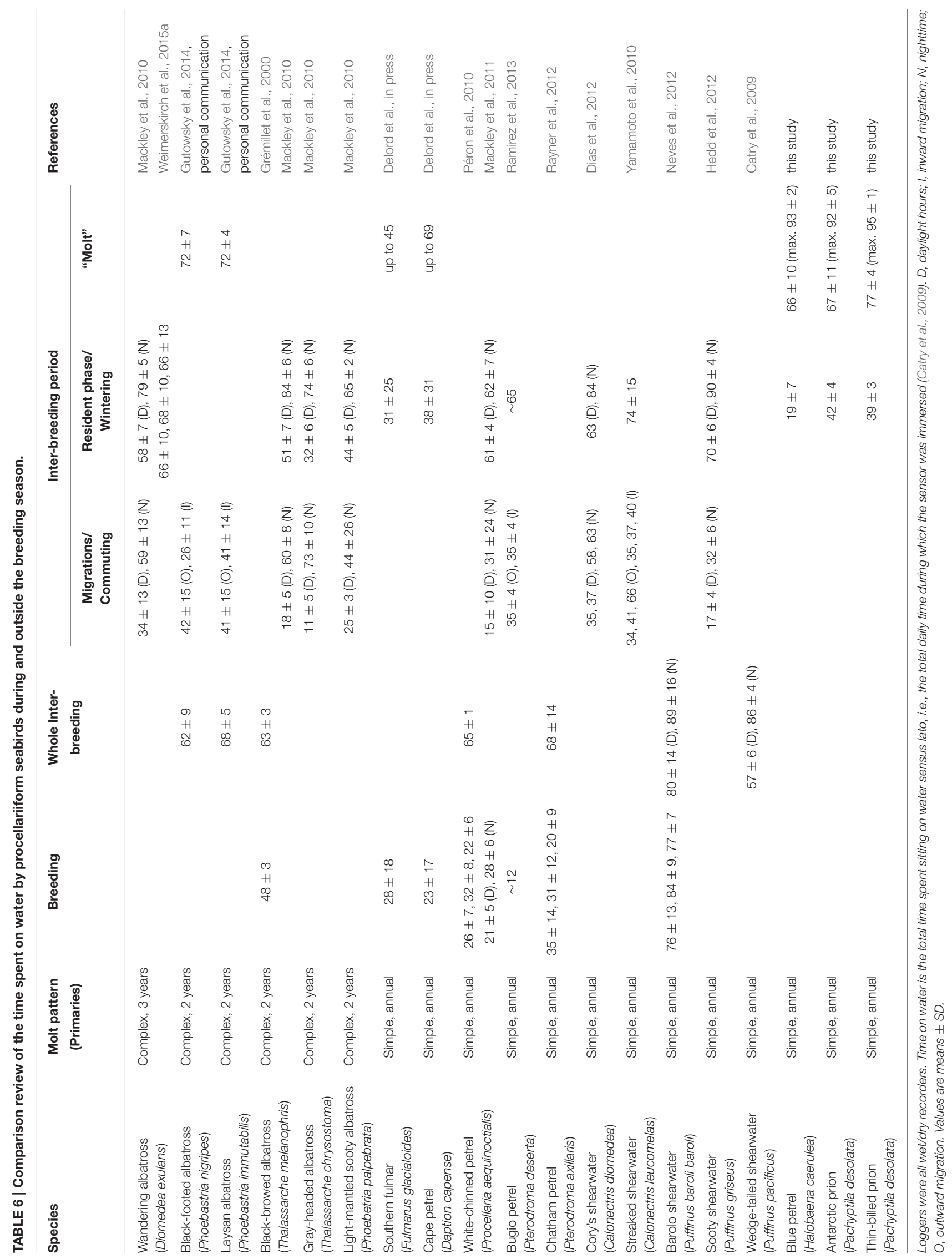


in Antarctic waters. The most likely explanation is that they were immature individuals, non-breeding adults or failed breeders, all found to differ in their molt strategy when compared to successful breeders (Warham, 1996). Primary $\delta^{13} \mathrm{C}$-values of AP depict latitudinal movements and suggest that $\mathrm{P} 1-\mathrm{P} 4$ were renewed simultaneously, thus highlighting the usefulness of sequential feather sampling to investigate migration and molt patterns (Cherel et al., 2000; Quillfeldt et al., 2010b; Gonzalez-Solis et al., 2011).

When compared to primaries, body feathers revealed higher variance in their isotopic values, thus indicating that some of them grew in habitats different from the core molting areas depicted by the GLS locations. This is in agreement with the little available information indicating that body feathers of Procellariiformes are replaced gradually over several months, mainly during the non-breeding period (Warham, 1996; Battam et al., 2010; Bugoni et al., 2015). A protracted body molt minimizes temporal overlap with active wing molt and thus lowers the associated nutrient and energetic costs of renewing all feather types simultaneously (but see Bugoni et al., 2015). It also minimizes effective insulation losses that may be energetically costly for seabirds when they increase time spent on water while water temperatures are low. A protracted renewal also means that measuring isotopic values of body feathers is a powerful tool to gather useful information on the whole inter-breeding period (Jaeger et al., 2010a), with the main limitation being that some body feathers may grow during the breeding season (Catry et al., 2013; Bourgeois and Dromzée, 2014).

\section{The Time-Budget of Non-Breeding Seabirds}

A review of the studies on Procellariiformes that used activity sensors consistently reported an increase in time spent on water during the whole inter-breeding period or during part of it when compared to migration and/or the breeding season (Table 6). The behavior occurred in different taxonomic groups (albatrosses, fulmarines, gadfly petrels, shearwaters) living in different marine environments (from the tropics to the poles, and in both oceanic and neritic waters). Two notable exceptions are species that are known to rest either on ice or on land, thus precluding efficient quantification of their time-budgets using wet/dry sensors (Thiers et al., 2014; Delord et al., in press). Four non-exclusive hypotheses could explain the increase in time spent sitting on water (Péron et al., 2010): (H1) lower energy requirement compared to breeding and migration, (H2) an opportunistic sit-and-wait foraging strategy in highly productive waters, (H3) interaction with other predators and fisheries that increases food availabily (e.g., natural prey, and offal and discards, respectively), and ( $\mathrm{H} 4)$ flight impairment due to molt. The present investigation adds substantial information to disentangle the potential factors involved. The highest time sitting on water of $\mathrm{AP}, \mathrm{TBP}$, and $\mathrm{BP}$ during the inter-breeding period corresponded to the renewal of flight feathers; hence, it does not support $\mathrm{H} 1$, because molt is an energy- and nutrient-demanding process. The behavior was recorded in both high (e.g., Antarctic zone) and medium/low (oceanic subtropical and tropical zones) productive waters, which is not in strict agreement with $\mathrm{H} 2$. In some cases, however, molt appears associated with food-rich areas (e.g., TBP and BP; see above). Finally, some species rarely associate with other consumers and/or are generally not ship-followers (e.g., $\mathrm{BP}$, prions), therefore, $\mathrm{H} 3$ can be discarded as a conclusive explanation.

All previously investigated seabird species are known to totally or partially molt their primaries during the inter-breeding period. In the few cases where the time window of molt is precise (BP) or strongly suspected (Hawaiian albatrosses), renewal of primaries temporally coincided with an increase in time spent on water (Gutowsky et al., 2014, present study). Accordingly, when active wing molt begins during late breeding (e.g., Southern fulmar Fulmarus glacialoides, Cape petrel Daption capense), daily time spent on water peaks in the late chick-rearing/early post-breeding period (Delord et al., in press). Notably, a transient increase in time spent on water occurs in species with contrasted molt patterns, namely small and medium-sized petrels with an annual complete renewal of primaries over 2-4 consecutive months (Delord et al., in press, this study), and albatrosses that molt only a part of their primaries every year or every 2 years (Gutowsky et al., 2014). Consequently, the most parcimonious explanation is that molt is the primary driving factor of time spent on water in non-breeding Procellariiformes (H4). This is certainly not the single explanatory factor for all species and $\mathrm{H} 1$ is certainly valid in some extent, because non-breeding birds are not central-place foragers and they have neither to restore quickly their energy reserves nor to feed chicks. However, the present work calls for a re-appraisial and re-analysis of already recorded at-sea activities of albatrosses, petrels and shearwaters using wet/dry sensors during the inter-breeding period. Variations in the intensity, duration and timing of the transient increase in time spent on water can be expected, especially in relationships with different molt patterns and wing-molt durations (Bridge, 2006). Finally, a general critical assessment of activity level in relation to molt is also needed in other seabird groups, because an increase in time spent on water during the inter-breeding period was already found in sulids (Garthe et al., 2012), skuas (Phillips et al., 2007; Magnusdottir et al., 2014; Weimerskirch et al., 2015b), and alcids (Mosbech et al., 2012), thus suggesting that it is potentially a main characteristic of flying seabird energy budget overall.

\section{AUTHOR CONTRIBUTIONS}

Study conception and design: $\mathrm{YC}, \mathrm{PQ}$, and $\mathrm{HW}$; acquisition of data, analysis and interpretation of data: YC, PQ, KD, and HW; manuscript draft and revision: $\mathrm{YC}, \mathrm{PQ}, \mathrm{KD}$, and $\mathrm{HW}$. All authors approved the publication.

\section{FUNDING}

The present work was supported financially and logistically by IPEV (Programme $\mathrm{N}^{\circ} 109, \mathrm{HW}$ ) and TAAF. PQ was supported by a grant of the Heisenberg program (DFG, Qu 148-5).

\section{ACKNOWLEDGMENTS}

The authors thank A. Corbeau, J. Ferrer-Obiol, M. Passerault, and T. Lacombe for fieldwork assistance, S. Ruault for seabird molecular sexing, A. Fromant for preparing some isotopic 
samples, G. Guillou for stable isotope analysis, and R.A. Phillips for helpful comments on the ms. Field procedures and animal manipulations were approved by the Animal Ethics Committee of the Institut Polaire Français Paul Emile Victor (IPEV), and by the Préfet of the Terres Australes et Antarctiques Françaises (TAAF).

\section{REFERENCES}

Afanasyev, V. (2004). A miniature daylight level and activity data recorder for tracking animals over long periods. Mem. Natl. Inst. Polar Res. 58, 227-233.

Barbraud, C., and Weimerskirch, H. (2003). Climate and density shape population dynamics of a marine top predator. Proc. R. Soc. Lond. B 270, 2111-2116. doi: $10.1098 / \mathrm{rspb} .2003 .2488$

Battam, H., Richardson, M., Watson, A. W. T., and Buttemer, W. A. (2010). Chemical composition and tissue energy density of the cuttlefish (Sepia apama) and its assimilation efficiency by Diomedea albatrosses. J. Comp. Physiol. B. Biochem. Syst. Environ. Physiol. 180, 1247-1255. doi: 10.1007/s00360-0100497-3

Bearhop, S., Waldron, S., Votier, S. C., and Furness, R. W. (2002). Factors that influence assimilation rates and fractionation of nitrogen and carbon stable isotopes in avian blood and feathers. Physiol. Biochem. Zool. 75, 451-458. doi: $10.1086 / 342800$

Beyer, H. L. (2004). Hawth's Analysis Tools for ArcGIS. Available online at: http:// www.spatialecology.com/htools/

Bourgeois, K., and Dromzée, S. (2014). Moulting strategies of the Yelkouan shearwater Puffinus yelkouan during the breeding season. J. Ornithol. 155, 265-271. doi: 10.1007/s10336-013-1011-y

Bridge, E. S. (2006). Influences of morphology and behavior on wing-molt strategies in seabirds. Mar. Ornithol. 34, 7-19.

Bugoni, L., Naves, L. C., and Furness, R. W. (2015). Moult of three Tristan da Cunha species sampled at sea. Antarct. Sci. 27, 240-251. doi: $10.1017 /$ S0954102014000583

Carey, M. J., Phillips, R. A., Silk, J. R. D., and Shaffer, S. A. (2014). Transequatorial migration of short-tailed shearwaters revealed by geolocators. Emu 114, 352-359. doi: 10.1071/MU13115

Carravieri, A., Bustamante, P., Churlaud, C., Fromant, A., and Cherel, Y. (2014). Moulting patterns drive within-individual variations of stable isotopes and mercury in seabird body feathers: implications for monitoring of the marine environment. Mar. Biol. 161, 963-968. doi: 10.1007/s00227-014-2394-x

Catry, P., Poisbleau, M., Lecoq, M., and Phillips, R. A. (2013). Differences in the timing and extent of annual moult of black-browed albatrosses Thalassarche melanophris living in contrasting environments. Polar Biol. 36, 837-842. doi: 10.1007/s00300-013-1309-5

Catry, T., Ramos, J. A., Le Corre, M., and Phillips, R. A. (2009). Movements, atsea distribution and behaviour of a tropical pelagic seabird: the wedge-tailed shearwater in the western Indian Ocean. Mar. Ecol. Prog. Ser. 391, 231-242. doi: $10.3354 /$ meps 07717

Cherel, Y., Bocher, P., de Broyer, C., and Hobson, K. A. (2002a). Food and feeding ecology of the sympatric thin-billed Pachyptila belcheri and Antarctic P. desolata prions at Iles Kerguelen, Southern Indian Ocean. Mar. Ecol. Prog. Ser. 228, 263-281. doi: 10.3354/meps228263

Cherel, Y., Bocher, P., Trouvé, C., and Weimerskirch, H. (2002b). Diet and feeding ecology of blue petrels Halobaena caerulea at Iles Kerguelen, Southern Indian Ocean. Mar. Ecol. Prog. Ser. 228, 283-299. doi: 10.3354/meps228283

Cherel, Y., Connan, M., Jaeger, A., and Richard, P. (2014). Seabird year-round and historical feeding ecology: blood and feather $\delta^{13} \mathrm{C}$ and $\delta^{15} \mathrm{~N}$ values document foraging plasticity of small sympatric petrels. Mar. Ecol. Prog. Ser. 505, 267-280. doi: 10.3354/meps10795

Cherel, Y., Fontaine, C., Richard, P., and Labat, J. P. (2010). Isotopic niches and trophic levels of myctophid fishes and their predators in the Southern Ocean. Limnol. Oceanogr. 55, 324-332. doi: 10.4319/lo.2010.55.1.0324

Cherel, Y., Hobson, K. A., and Weimerskirch, H. (2000). Using stable-isotope analysis of feathers to distinguish moulting and breeding origins of seabirds. Oecologia 122, 155-162. doi: 10.1007/PL00008843

Cherel, Y., Phillips, R. A., Hobson, K. A., and McGill, R. (2006). Stable isotope evidence of diverse species-specific and individual wintering strategies in seabirds. Biol. Lett. 2, 301-303. doi: 10.1098/rsbl.2006.0445
Connan, M., Cherel, Y., and Mayzaud, P. (2007). Lipids from stomach oil of procellariiform seabirds document the importance of myctophid fish in the Southern Ocean. Limnol. Oceanogr. 52, 2445-2455. doi: 10.4319/lo.2007.52.6.2445

Connan, M., Mayzaud, P., Trouvé, C., Barbraud, C., and Cherel, Y. (2008). Interannual dietary changes and demographic consequences in breeding blue petrels from Kerguelen Islands. Mar. Ecol. Prog. Ser. 373, 123-135. doi: 10.3354/meps07723

Croxall, J. P., Silk, J. R. D., Phillips, R. A., Afanasyev, V., and Briggs, D. R. (2005). Global circumnavigations: tracking year-round ranges of nonbreeding albatrosses. Science 307, 249-250. doi: 10.1126/science.1106042

Delord, K., Barbraud, C., Bost, C. A., Cherel, Y., Guinet, C., and Weimerskirch, H. (2013). Atlas of top predators from French Southern Territories in the Southern Indian Ocean. CEBC-CNRS. 252. doi: 10.15474/AtlasTopPredatorsOI_CEBC.CNRS_FrenchSouthernTerritories

Delord, K., Pinet, P., Pinaud, D., De Grissac, S., Lewden, A., Cherel, Y., et al. (in press). Species-specific foraging strategies and segregation mechanisms of sympatric antarctic fulmarine petrels during the annual cycle. Ibis.

De Solla, S. R., Bonduriansky, R., and Brooks, R. J. (1999). Eliminating autocorrelation reduces biological relevance of home range estimates. J. Anim. Ecol. 68, 221-234. doi: 10.1046/j.1365-2656.1999.00279.x

Dias, M. P., Granadeiro, J. P., and Catry, P. (2012). Do seabirds differ from other migrants in their travel arrangements? On route strategies of Cory's shearwater during its trans-equatorial journey. PLOS ONE 7:e49376. doi: 10.1371/journal.pone.0049376

Egevang, C., Stenhouse, I. J., Phillips, R. A., Petersen, A., Fox, J. W., and Silk, J. R. D. (2010). Tracking of Arctic terns Sterna paradisea reveals longest animal migration. Proc. Natl. Acad. Sci. U.S.A. 107, 2078-2081. doi: 10.1073/pnas. 0909493107

Frederiksen, M., Daunt, F., Harris, M. P., and Wanless, S. (2008). The demographic impact of extreme events: stochastic weather drives survival and population dynamics in a long-lived seabird. J. Anim. Ecol. 77, 1020-1029. doi: 10.1111/j.1365-2656.2008.01422.x

Freeman, R., Dean, B., Kirk, H., Leonard, K., Phillips, R. A., Perrins, C. M., et al. (2013). Predictive ethoinformatics reveal the complex migratory behaviour of a pelagic seabird, the Manx shearwater. J. R. Soc. Interface 10, 20130279. doi: 10.1098/rsif.2013.0279

Fugler, S. R., Hunter, S., Newton, I. P., and Steele, W. K. (1987). Breeding biology of blue petrels Halobaena caerulea at the Prince Edward Islands. Emu 87, 103-110. doi: 10.1071/MU9870103

Garthe, S., Ludynia, K., Hüppop, O., Kubetzki, U., Meraz, J. F., and Furness, R. W. (2012). Energy budgets reveal equal benefits of varied migration strategies in northern gannets. Mar. Biol. 159, 1907-1915. doi: 10.1007/s00227-0121978-6

Gonzalez-Solis, J., Smyrli, M., Militao, T., Grémillet, D., Tveraa, T., Phillips, R. A., et al. (2011). Combining stable isotope analyses and geolocation to reveal kittiwake migration. Mar. Ecol. Prog. Ser. 435, 251-261. doi: $10.3354 /$ meps09233

Grémillet, D., Wilson, R. P., Wanless, S., and Chater, T. (2000). Black-browed albatrosses, international fisheries and the Patagonian Shelf. Mar. Ecol. Prog. Ser. 195, 269-280. doi: 10.3354/meps195269

Grosbois, V., and Thompson, P. M. (2005). North Atlantic climate variation influences survival in adult fulmars. Oikos 109, 273-290. doi: 10.1111/j.00301299.2005.13774.x

Guinet, C., Chastel, O., Koudil, M., Durbec, J. P., and Jouventin, P. (1998). Effects of warm sea-surface temperature anomalies on the blue petrel at the Kergueken Islands. Proc. R. Soc. Lond. B 265, 1001-1006. doi: 10.1098/rspb.1998.0390

Gutowsky, S. E., Gutowsky, L. F. G., Jonsen, I. D., Leonard, M. L., Naughton, M. B., Romano, M. D., et al. (2014). Daily activity budgets reveal a quasi-flightless stage during non-breeding in Hawaiian albatrosses. Movement Ecol. 2:23. doi: 10.1186/s40462-014-0023-4 
Harper, P. C. (1980). The field identification and distribution of the prions (genus Pachyptila), with particular reference to the identification of storm-cast material. Notornis 27, 235-286.

Hedd, A., Montevecchi, W. A., Otley, H., Phillips, R. A., and Fifield, D. A. (2012). Trans-equatorial migration and habitat use by sooty shearwaters Puffinus griseus from the South Atlantic during the nonbreeding season. Mar. Ecol. Prog. Ser. 449, 277-290. doi: 10.3354/meps09538

Hobson, K. A., and Clark, R. G. (1992). Assessing avian diets using stable isotopes I: turnover of ${ }^{13} \mathrm{C}$ in tissues. Condor 94, 181-188. doi: 10.2307/ 1368807

Hobson, K. A., and Clark, R. G. (1993). Turnover of ${ }^{13} \mathrm{C}$ in cellular and plasma fractions of blood: implications for non destructive sampling in avian dietary studies. Auk 110, 638-641. doi: 10.2307/4088430

Jaeger, A., Blanchard, P., Richard, P., and Cherel, Y. (2009). Using carbon and nitrogen isotopic values of body feathers to infer inter- and intra-individual variations of seabird feeding ecology during moult. Mar. Biol. 156, 1233-1240. doi: 10.1007/s00227-009-1165-6

Jaeger, A., Connan, M., Richard, P., and Cherel, Y. (2010a). Use of stable isotopes to quantify seasonal changes of trophic niche and levels of population and individual specialisation in seabirds. Mar. Ecol. Prog. Ser. 401, 269-277. doi: $10.3354 /$ meps08380

Jaeger, A., Lecomte, V. J., Weimerskirch, H., Richard, P., and Cherel, Y. (2010b). Seabird satellite tracking validates the use of latitudinal isoscapes to depict predators' foraging areas in the Southern Ocean. Rapid Commun. Mass Spectrom. 24, 3456-3460. doi: 10.1002/rcm.4792

Mackley, E. K., Phillips, R. A., Silk, J. R. D., Wakefield, E. D., Afanasyev, V., Fox, J. W., et al. (2010). Free as a bird? Activity patterns of albatrosses during the nonbreeding period. Mar. Ecol. Prog. Ser. 406, 291-303. doi: 10.3354/meps08532

Mackley, E. K., Phillips, R. A., Silk, J. R. D., Wakefield, E. D., Afanasyev, V., and Furness, R. W. (2011). At-sea activity patterns of breeding and nonbreeding white-chinned petrels Procellaria aequinoctialis from South Georgia. Mar. Biol. 158, 429-438. doi: 10.1007/s00227-010-1570-x

Magnusdottir, E., Leat, E. H. K., Bourgeon, S., Jonsson, J. E., Phillips, R. A., Strom, H., et al. (2014). Activity patterns of wintering great skuas Stercorarius skua. Bird Study 61, 301-308. doi: 10.1080/00063657.2014.940839

Marchant, S., and Higgins, P. J. (1990). Handbook of Australian, New Zealand and Antarctic Birds, Vol. 1. Melbourne, VIC: Oxford University Press.

Mattern, T., Masello, J. F., Ellenberg, U., and Quillfeldt, P. (2015). Actave.net a web-based tool for the analysis of seabird activity patterns from saltwater immersion geolocators. Methods Ecol. Evol. 6, 859-864. doi: 10.1111/2041210X.12398

McKnight, A., Irons, D. B., Allyn, A. J., Sullivan, K. M., and Suryan, R. M. (2011). Winter dispersal and activity patterns of post-breeding black-legged kittiwakes Rissa tridactyla from Prince William Sound, Alaska. Mar. Ecol. Prog. Ser. 442, 241-253. doi: 10.3354/meps09373

Mosbech, A., Johansen, K. L., Bech, N. I., Lyngs, P., Harding, A. M. A., Egevang, C., et al. (2012). Inter-breeding movements of little auks Alle alle reveal a key post-breeding staging area in the Greenland Sea. Polar Biol. 35, 305-311. doi: 10.1007/s00300-011-1064-4

Navarro, J., Cardador, L., Brown, R., and Phillips, R. A. (2015). Spatial distribution and ecological niches of non-breeding planktivorous petrels. Sci. Rep. 5:12164. doi: 10.1038/srep12164

Navarro, J., Votier, S. V., Aguzzi, J., Chiesa, J. J., Forero, M. G., and Phillips, R. A. (2013). Ecological segregation in space, time and trophic niche of sympatric planktivorous petrels. PLoS ONE 8:e62897. doi: 10.1371/journal.pone.00 62897

Neves, V. C., Bried, J., Gonzalez-Solis, J., Roscales, J. L., and Clarke, M. R. (2012). Feeding ecology and movements of the Barolo shearwater Puffinus baroli baroli in the Azores, NE Atlantic. Mar. Ecol. Prog. Ser. 452, 269-285. doi: 10.3354/meps09670

Nevoux, M., and Barbraud, C. (2006). Relationships between sea ice concentration, sea surface temperature and demographic traits of thin-billed prions. Polar Biol. 29, 445-453. doi: 10.1007/s00300-005-0075-4

Orben, R. A., Irons, D. B., Paredes, R., Roby, D. D., Phillips, R. A., and Shaffer, S. A. (2015). North or south? Niche separation of endemic red-legged kittiwakes and sympatric black-legged kittiwakes during their non-breeding migrations. J. Biogeogr. 42, 401-412. doi: 10.1111/jbi.12425
Park, Y. H., and Gambéroni, L. (1997). Cross-frontal exchange of Antarctic intermediate water and Antarctic bottom water in the Crozet basin. Deep Sea Res. II 44, 963-986. doi: 10.1016/S0967-0645(97)00004-0

Péron, C., Delord, K., Phillips, R. A., Charbonnier, Y., Marteau, C., Louzao, M., et al. (2010). Seasonal variation in oceanographic habitat and behaviour of white-chinned petrels Procellaria aequinoctialis from Kerguelen Island. Mar. Ecol. Prog. Ser. 416, 267-284. doi: 10.3354/meps08785

Phillips, R. A., Catry, P., Silk, J. R. D., Bearhop, S., McGill, R., Afanasyev, V., et al. (2007). Movements, winter distribution and activity patterns of Falkland and brown skuas: insights from loggers and isotopes. Mar. Ecol. Prog. Ser. 345, 281-291. doi: 10.3354/meps06991

Phillips, R. A., Silk, J. R. D., Croxall, J. P., Afanasyev, V., and Briggs, D. R. (2004). Accuracy of geolocation estimates for flying seabirds. Mar. Ecol. Prog. Ser. 266, 265-272. doi: 10.3354/meps266265

Pinet, P., Jaeger, A., Cordier, E., Potin, G., and Le Corre, M. (2011). Celestial moderation of tropical seabird behavior. PLOS ONE 6:e27663. doi: 10.1371/journal.pone.0027663

Quillfeldt, P., Cherel, Y., Delord, K., and Weimerskirch, H. (2015a). Cool, cold, or colder? Spatial segregation of prions and blue petrels is explained by differences in preferred sea surface temperatures. Biol. Lett. 11, 20141090. doi: 10.1098/rsbl.2014.1090

Quillfeldt, P., Cherel, Y., Masello, J. F., Delord, K., McGill, R. A. R., Furness, R. W., et al. (2015b). Half a world apart? Overlap in nonbreeding distributions of Atlantic and Indian Ocean thin-billed prions. PLoS ONE 10:e0125007. doi: 10.1371/journal.pone.0125007

Quillfeldt, P., Masello, J. F., McGill, R. A. R., Adams, M., and Furness, R. W. (2010a). Moving polewards in winter: a recent change in the migratory strategy of a pelagic seabird? Front. Zool. 7:15. doi: 10.1186/1742-99 94-7-15

Quillfeldt, P., Masello, J. F., Navarro, J., and Phillips, R. A. (2013). Year-round distribution suggests spatial segregation of two small petrel species in the South Atlantic. J. Biogeogr. 40, 430-441. doi: 10.1111/jbi.12008

Quillfeldt, P., McGill, R. A. R., Furness, R. W., Möstl, E., Ludynia, K., and Masello, J. F. (2012). Impact of miniature geolocation loggers on a small petrel, the thin-billed prion Pachyptila belcheri. Mar. Biol. 159, 1809-1816. doi: 10.1007/s00227-012-1971-0

Quillfeldt, P., Voigt, C. C., and Masello, J. F. (2010b). Plasticity versus repeatability in seabird migratory behaviour. Behav. Ecol. Sociobiol. 64, 1157-1164. doi: 10.1007/s00265-010-0931-2

Ramirez, I., Paiva, V. H., Menezes, D., Silva, I., Phillips, R. A., Ramos, J. A., et al. (2013). Year-round distribution and habitat preferences of the Bugio petrel. Mar. Ecol. Prog. Ser. 476, 269-284. doi: 10.3354/meps10083

Rayner, M. J., Taylor, G. A., Gummer, H. D., Phillips, R. A., Sagar, P. M., Shaffer S. A., et al. (2012). The breeding cycle, year-round distribution and activity patterns of the endangered Chatham petrel (Pterodroma axillaris). Emu 112, 107-116. doi: 10.1071/MU11066

Schroeder, I. D., Sydeman, W. J., Sarkar, N., Thompson, S. A., Bograd, S. J., and Schwing, F. B. (2009). Winter pre-conditioning of seabird phenology in the California Current. Mar. Ecol. Prog. Ser. 393, 211-223. doi: 10.3354/meps 08103

Shaffer, S. A., Tremblay, Y., Weimerskirch, H., Scott, D., Thompson, D. R., Sagar, P. M., et al. (2006). Migratory shearwaters integrate oceanic resources across the Pacific Ocean in an endless summer. Proc. Natl. Acad. Sci. U.S.A. 103, 12799-12802. doi: 10.1073/pnas.0603715103

Stenhouse, I. J., Egevang, C., and Phillips, R. A. (2012). Trans-equatorial migration, staging sites and wintering area of Sabine's gulls Larus sabini in the Atlantic Ocean. Ibis 154, 42-51. doi: 10.1111/j.1474-919X.2011.01180.x

Thiébot, J. B., Cherel, Y., Trathan, P. N., and Bost, C. A. (2012). Coexistence of oceanic predators on wintering areas explained by population-scale foraging segregation in space or time. Ecology 93, 122-130. doi: 10.1890/11-0385.1

Thiers, L., Delord, K., Barbraud, C., Phillips, R. A., Pinaud, D., and Weimerskirch, H. (2014). Foraging zones of the two sibling species of giant petrels in the Indian Ocean throughout the annual cycle: implications for their conservation. Mar. Ecol. Prog. Ser. 499, 233-248. doi: 10.3354/meps 10620

Warham, J. (1996). The Behaviour, Population Biology and Physiology of the Petrels. San Diego, USA: Academic Press.

Weimerskirch, H., Delord, K., Guitteaud, A., Phillips, R. A., and Pinet, P. (2015a). Extreme variation in migration strategies between and 
within wandering albatross populations during their sabbatical year, and their fitness consequences. Sci. Rep. 5:8853. doi: 10.1038/srep 08853

Weimerskirch, H., Lallemand, J., and Martin, J. (2005). Population sex ratio variation in a monogamous long-lived bird, the wandering albatross. J. Anim. Ecol. 74, 285-291. doi: 10.1111/j.1365-2656.2005. 00922.x

Weimerskirch, H., Tarroux, A., Chastel, O., Delord, K., Cherel, Y., and Descamps, S. (2015b). Population-specific wintering distributions of adult south polar skuas over three oceans. Mar. Ecol. Prog. Ser. 538, 229-237. doi: 10.3354/meps11465

Weimerskirch, H., and Wilson, R. P. (2000). Oceanic respite for wandering albatrosses. Nature 406, 955-956. doi: 10.1038/35023068

Weimerskirch, H., Zotier, R., and Jouventin, P. (1989). The avifauna of the Kerguelen Islands. Emu 89, 15-29. doi: 10.1071/MU9 890015
Yamamoto, T., Takahashi, A., Yoda, K., Katsumata, N., Sato, K., and Trathan, P. N. (2010). At-sea distribution and behavior of streaked shearwaters (Calonectris leucomelas) during the nonbreeding period. Auk 127, 871-881. doi: 10.1525/auk.2010.10029

Conflict of Interest Statement: The authors declare that the research was conducted in the absence of any commercial or financial relationships that could be construed as a potential conflict of interest.

Copyright (c) 2016 Cherel, Quillfeldt, Delord and Weimerskirch. This is an openaccess article distributed under the terms of the Creative Commons Attribution License (CC BY). The use, distribution or reproduction in other forums is permitted, provided the original author(s) or licensor are credited and that the original publication in this journal is cited, in accordance with accepted academic practice. No use, distribution or reproduction is permitted which does not comply with these terms. 